\title{
Influence of Vineyard Inter-Row Groundcover Vegetation Management on Arthropod Assemblages in the Vineyards of North-Eastern Italy
}

\author{
Giulia Zanettin ${ }^{1} \mathbb{D}$, Angela Bullo ${ }^{1}$, Alberto Pozzebon ${ }^{1} \mathbb{C}$, Giovanni Burgio ${ }^{2}$ and Carlo Duso ${ }^{1, *} \mathbb{C}$ \\ 1 Department of Agronomy, Food, Natural Resources, Animals and Environment (DAFNAE), University of \\ Padova, Viale dell’Università 16, Agripolis, Legnaro, 35020 Padova, Italy; giuliazanettin22@gmail.com (G.Z.); \\ angelabullo@aruba.it (A.B.); alberto.pozzebon@unipd.it (A.P.) \\ 2 Department of Agricultural and Food Sciences (DISTAL), Alma Mater Studiorum-Università di Bologna, \\ Viale G. Fanin, 42, 40127 Bologna, Italy; giovanni.burgio@unibo.it \\ * Correspondence: carlo.duso@unipd.it
}

check for updates

Citation: Zanettin, G.; Bullo, A.; Pozzebon, A.; Burgio, G.; Duso, C. Influence of Vineyard Inter-Row Groundcover Vegetation

Management on Arthropod Assemblages in the Vineyards of North-Eastern Italy. Insects 2021, 12, 349. https://doi.org/10.3390/ insects12040349

Academic Editor: Domenico Bosco

Received: 5 February 2021

Accepted: 10 April 2021

Published: 14 April 2021

Publisher's Note: MDPI stays neutral with regard to jurisdictional claims in published maps and institutional affiliations.

Copyright: (c) 2021 by the authors. Licensee MDPI, Basel, Switzerland. This article is an open access article distributed under the terms and conditions of the Creative Commons Attribution (CC BY) license (https:/ / creativecommons.org/licenses/by/ $4.0 /)$.
Simple Summary: Habitat simplification and use of pesticides in vineyard agro-ecosystems simplified arthropod communities, reducing natural pest control. In this context, habitat management practices could be useful strategies to provide fundamental sources for sustaining natural enemies. The effects of habitat management practices on pests and beneficial arthropods were evaluated in vineyards of North-eastern Italy through different field experiments. We reduced mowing frequency of inter-row spontaneous grasses, compared different timing of mowing of a green manure mixture, and different green manure mixtures. The abundance of key natural enemies (e.g., predatory mites, parasitic wasps and spiders) and some grapevine leafhoppers increased when the grass mowing frequency was reduced. Many beneficial arthropods increased in numbers in organic vineyards. Late mowing of green manure favored spiders and parasitic wasps but not herbivores associated with grapevines. The experiments on the comparison of green manure mixtures did not significantly affect the arthropod communities. Groundcover management practices could enhance beneficial arthropod abundance, but the adoption of this practice should be carefully evaluated when pests occur.

Abstract: In this study, the effects of habitat management practices on both pests and beneficial arthropods were evaluated in vineyards of North-eastern Italy through different field experiments: (1) mowing of inter-row spontaneous grasses in conventional and organic vineyards, (2) different timing of mowing of a green manure mixture, and (3) comparing different green manure mixtures. The first experiment followed a split-plot design, while randomized block design was used in the second and third experiment. In each experiment arthropods were sampled using different methods: leaf sampling, beating and sweep net sampling. Non-mowed spontaneous grasses in inter-rows of vineyards favored the abundance of natural enemies (e.g., predatory mites, parasitic wasps and spiders), and sometimes grapevine leafhoppers. Many arthropod species were recorded in higher numbers in organic vineyards. Late mowing of green manure favored beneficial arthropods (e.g., spiders and parasitic wasps), while it did not influence herbivore density. Groundcover management practices, aimed at increasing plant biodiversity in vineyards, could be a useful tool to enhance beneficial arthropod abundance, although the adoption of this practice should be carefully evaluated when pests occur. Semi-natural areas can contribute to create a more pest-stable agro-ecosystem and should be integrated with appropriate ecological infrastructures surrounding vineyards.

Keywords: grapevine; habitat management; organic viticulture; arthropod pests; biological control

\section{Introduction}

In recent decades the intensification in viticulture has been characterized by the expansion of monoculture and the consequent reduction of semi-natural areas, thus leading 
to a decrease of food resources (such as nectar, pollen, alternate prey), sheltering and overwintering sites for beneficial organisms; this phenomenon has also been reported for other crops [1-3]. In this scenario, the deployment of broad-spectrum pesticides further simplifies arthropod communities favoring pest outbreaks [4,5]. In intensive agroecosystems, the activity of natural enemies has decreased, for the impoverishment of trophic webs and the lack of synchronization of the beneficials with pests, with dramatic consequences for biological control [1,6-10].

Habitat management practices in vineyards, such as the management of resident floor vegetation and the use of cover crops, are useful strategies which provide alternative prey or other food sources and refuge sites for predators and parasitoids, increasing the diversity and abundance of natural enemies [11,12]. In fact, conserving and/or increasing plant biodiversity may provide fundamental resources for beneficial arthropods, contributing to create an appropriate ecological infrastructure within and around vineyards, with implications for more pest-stable agro-ecosystems [11-14]. In Californian vineyards, spontaneous groundcover grass management resulted in a habitat modification which greatly enhanced population densities of predatory mites [15]. Access to buckwheat flowers (Fagopyrum esculentum Moench) or vetch (Vicia sativa L.) extrafloral nectaries increased the longevity and fecundity of Anagyrus pseudococci (Girault), the main parasitoid of the vine mealybug Planococcus ficus (Signoret) (Hemiptera: Pseudococcidae) [16]. In European vineyards, predatory mites are favored by pollen availability [17,18]. Altieri et al. [19] suggested a guideline for the implementation of habitat management strategies in vineyards, by assessing the presence of the key natural enemies in the cultivated area and in the surrounding vegetation. After matching the plant resources existing in and around the vineyard with the needs of natural enemies, other plant species can be added to provide shelter and food sources, taking into consideration the biology of those beneficials to favor. It is important to carefully select plants to provide nectar and pollen sources and assess their influence on pests and natural enemies. Studies on the impact of different nectar sources on parasitoid survival and fecundity provided important information on which plant species to preserve or introduce into an agro-ecosystem [20]. The use of companion plants has been suggested to promote biological control in agro-ecosystems, including vineyards [19]. In the choice of plant species, the availability, the flower attractiveness and its characteristics (e.g., size, shape and color), food accessibility, and the quality in nutritional value must be considered when choosing flowering plants to attract beneficial arthropods, since they determine which insects will be able to access the flower's pollen and nectar [20]. Additionally, the timing of blossom is an important feature, since many natural enemies, which are active only as adults and for a short period during the growing season, need suitable food sources in the early season when preys are scarce [19].

The aim of this study was to evaluate the effects of some habitat management practices on pests and beneficials in vineyards located in North-eastern Italy. In a first experiment, the influence of the non-mowed native spontaneous grass of vineyard inter-rows was assessed. In a second experiment, the effect of the different timing of a commercial green manure mowing was tested. Finally, in a third experiment, the influence of different green manure mixtures, used by farmers to improve the soil characteristics, was evaluated.

\section{Materials and Methods}

\subsection{Influence of Non-Mowed Spontaneous Vegetation on Arthropod Assemblages}

\subsubsection{Study Area}

The study was conducted in the 2016 and 2017 growing seasons in the Conegliano Valdobbiadene Prosecco Superiore DOCG area (Treviso province, Veneto region). For this study, two conventional and two organic (according to EU Reg. 889/2008) managed vineyards were selected. In the second year, three vineyards remained the same while one was changed. In the study area, insecticide applications were mandatory to control Scaphoideus titanus Ball (Hemiptera: Cicadellidae), the main vector of the phytoplasma agent of Flavescence dorée [21]. Thiamethoxam-based products were the most 
used in the conventional vineyards, while pyrethrins were mostly sprayed in the organic vineyards. During the two years of investigation, insecticide applications were applied against $S$. titanus in late June, while during the sampling period, neither insecticide nor acaricide treatments were applied. The selected vineyards were situated at an altitude ranging between 93 and $274 \mathrm{~m}$ a.s.l. Glera, the typical cultivar of this area, was cultivated in the selected vineyards. Spontaneous vegetation was homogeneous among the studied vineyards and characterized by various plant species, particularly: Amaranthus retroflexus L., Chenopodium album L., Convolvulus arvensis L., Cynodon dactylon (L.) Pers., Dactylis glomerata L., Dacus carota L., Digitaria sp., Hordeum murinum L., Plantago lanceolata L., Plantago major L., Poa pratensis L., Ranunculus acris L., Rumex acetosa L., Setaria spp., Silene alba (Miller) Krause, Sorghum halepense (L.) Pers., Taraxacum officinalis Weber ex F.H.Wigg., Trifolium pratensis L., Trifolium repens L., and Urtica dioica $\mathrm{L}$.

\subsubsection{Experimental and Sampling Design}

Experiments were carried out in four vineyards (two conventionally and two organically managed). Two different inter-row groundcover vegetation management strategies were compared: non-mowed (NM) and frequently mowed (FM). NM plots consisted of four inter-rows: a mowed inter-row alternated to a subsequent non-mowed inter-row. A FM plot consisted of four subsequent inter-rows in which the vegetation was mowed to a few centimeters above the ground to prevent flowering. A hammer mulcher was used to cut the inter-row vegetation, while the sub-row weeds were mechanically removed (flat blade). Each treatment was performed in an area of $160 \mathrm{~m}^{2}$ (four subsequent $20 \mathrm{~m}$ long inter-rows) and replicated twice in each vineyard, for a total of 16 plots (eight conventionally and eight organically managed). The experiment started in mid-July after the insecticide applications against $S$. titanus. Since that time, groundcover vegetation was managed according to the experimental design. In NM plots mowing was carried out only once as climatic conditions were unfavorable to grass growth. The first sampling was performed in late July when most of the plants were flowering. Three samplings on grapevine leaves were carried out in 2016 and two samplings in 2017, with the last samplings performed two weeks before grape harvest (details of the sampling techniques are reported in Section 2.4).

\subsection{Influence of the Timing of Green Manure Mowing on Arthropod Assemblages 2.2.1. Study Area}

To investigate the effect of different timing of a commercial green manure mowing on the presence and the abundance of arthropods, a field experiment was performed in an organic vineyard located at Cessalto $\left(45^{\circ} 42^{\prime} 50.40^{\prime \prime} \mathrm{N}, 12^{\circ} 36.55 .44^{\prime \prime} \mathrm{E}, 3 \mathrm{~m}\right.$ a.s.l., Treviso province, North-eastern Italy) in 2017. The grapevine variety was Glera, SO4 was used as rootstock, the grapevine training system was Sylvoz, and the planting system was $2.70 \times 1.20 \mathrm{~m}$, corresponding to about 3000 vines/ha. The soil was characterized by a medium dough-clayey structure.

\subsubsection{Experimental and Sampling Design}

Three different management strategies of the vineyard inter-row groundcover were compared:

(1) "Standard green manure" (Stand-GM), where vegetation was mowed when most of plants of the mixture were flowering, as traditionally done by the growers.

(2) "Green manure with a more prolonged flowering period" (Late-GM), where vegetation was mowed when all the plants of the mixture finished flowering.

(3) "Control", where inter-rows were mowed before plants started to blossom.

(4) Each treatment was replicated in four plots of $486 \mathrm{~m}^{2}$ comprising nine $20 \mathrm{~m}$ long inter-rows. In treatments with green manure, a commercial seed mixture (Semfor s.r.l. San Pietro di Morubio, VR, Italy) was sown in three out of nine inter-rows. In the experimental vineyard, replicates were assigned to the three treatments following a completely randomized block design. The mixture was sown in October 2016 using 
a disc seed drill (dose $11 \mathrm{~g} / \mathrm{m}^{2}$ ). The composition of the green manure mixture is reported below (Table 1).

Table 1. Composition of the green manure mixtures used in the experiment on the influence of the timing of green manure mowing on arthropod assemblages.

\begin{tabular}{cccc}
\hline Common Name & Scientific Name & Cultivar & Pure Seed (\%) \\
\hline Rye & Secale cereale L. & Conduct & 15 \\
\hline Triticale & hybrid of wheat (Triticum) and rye (Secale) & Oxygen & 20 \\
\hline Oats & Avena sativa L. & Novella Antonia & 15 \\
\hline Vetch & Vicia sativa L. & Mikaela & 13 \\
\hline Flax & Linum usitatissimum L. & Sideral & 3 \\
\hline White mustard & Sinapis alba L. & Abraham & 3 \\
\hline Horseradish & Brassica rapa subsp. campestris L. & Carwoodi & 4 \\
\hline Kale & Brassica oleracea L. & Malwira & 3 \\
\hline Rape & Brassica napus L. & Bonar & Stala \\
\hline Blue tansy & Phacelia tanacetifolia Benth. & 5 \\
\hline
\end{tabular}

The mowing of control plots was performed at the end of March 2017, before plants started to blossom. Brassicaceae species of the mixture started to blossom at the beginning of April 2017 (grapevine bud burst), Poaceae and other families later. The first sampling on grapevine leaves was performed on May 24, when most plant species present in the green manure plots were blossoming. Stand-GM plots were mowed few days later, while plants continued to blossom in Late-GM plots. The second sampling was done on June 16. Then, Late-GM plots were mowed. The last sampling was performed on July 17 when all plots were mowed. During the sampling period neither insecticide nor acaricide treatments were applied (details of the sampling techniques are reported in Section 2.4).

\subsection{Influence of Different Green Manure Mixtures on Arthropod Assemblages}

\subsubsection{Study Area}

This experiment was carried out in an organic vineyard located at Carbonera $\left(45^{\circ} 41^{\prime} 4.20^{\prime \prime}\right.$ $\mathrm{N}, 12^{\circ} 17^{\prime} 7.44^{\prime \prime} \mathrm{E}, 30 \mathrm{~m}$ a.s.l., Treviso province, North-eastern Italy) in 2018 . The variety was Raboso Piave, $\mathrm{SO} 4$ was used as rootstock, the wine training system was Sylvoz and the planting system was $2.70 \times 1.20 \mathrm{~m}^{2}$ corresponding to 3000 vines/ha. The soil was characterized by a medium dough structure, with a $70 \%$ of skeleton.

\subsubsection{Experimental and Sampling Design}

Three different mixtures of green manure were compared with an untreated control:

(1) "MIX-1": Avena sativa L. cv Prevision + commercial mixture composed by buckwheat (KF 83\%, RH 99.5\%) (30\%), Pisum sativum L. cv Arkta (20\%), Vicia sativa cv Marianna (20\%), Lupinus augustifolium L. cv Tango (10\%), Trifolium incarnatum L. cv Tardivo (10\%), Trifolium alexandrinum L. cv Marmilla (8\%) and Phacelia tanacetifolia cv Natra (2\%);

(2) "MIX-2": Lolium multiflorum Lam. Cv Furore (35\%), Avena sativa L. cv Teobd40 (15\%), Hordeum vulgare L. cv Tazio (10\%), Trifolium alexandrinum cv Erix (20\%) and Vicia sativa cv Marianna (20\%);

(3) "MIX-3": Rye (Secale cereale L. cv Dukato, 55\%) and Vetch (Vicia villosa Roth cv Minnie, 45\%);

(4) "Control", in which the inter-row groundcover was mowed before the blossom.

Treatments were randomly replicated four times and each replicate consisted of a single inter-row ( $2.70 \mathrm{~m}$ large and $125 \mathrm{~m}$ long). The distance between each plot was about $3 \mathrm{~m}$. Seed mixtures were sown at the beginning of November 2017 and started to blossom 
at the beginning of May 2018. The control plots were mowed on 30 April 2018, while the other plots were not mowed. In this experiment, leaf sampling was performed from May to mid-June 2018 for a total of three sampling dates. During the sampling period neither insecticide nor acaricide treatments were applied.

\subsection{Sampling Methods}

Different techniques were applied to sample arthropods: manual collection of grapevine leaves and beating and sweep net samplings. In the experiment devoted to the comparison of different green manure mixtures, only the collection of grapevine leaves was performed. All these sampling techniques were carried out in the central part of each plot. Details of the sampling techniques are reported below.

\subsubsection{Leaf Sampling}

Field sampling was performed during the three experiments to evaluate the abundance of arthropods on grapevine leaves. This sampling was mainly focused on the assessment of spider mites (Acari: Tetranychidae), predatory mites (Acari: Phytoseiidae), leafhoppers (Hemiptera: Cicadellidae) and mealybugs (Hemiptera: Pseudococcidae); besides these taxa, other natural enemies were counted. Twenty-five leaves per replicate were randomly collected from the vine canopy and immediately transferred to the laboratory where they were observed under a Wild M3C stereomicroscope (10-40× magnification) to assess the identity and abundance of arthropod species. In the experiment on the influence of nonmowed spontaneous vegetation, the parasitism rate of leafhopper eggs by Hymenoptera Mymaridae was evaluated dividing the number of the parasitoid emerging holes by the sum of the number of nymph emergence holes and parasitoid emergence holes.

\subsubsection{Beating Net Sampling}

In the first two experiments, a beating net $(1 \times 1 \mathrm{~m})$ was used to collect arthropods from the vine canopy. Each beating net sample included a total of 4 sub-samples ( $1 \mathrm{~m}$ of vine canopy row) per each plot. The beating net was positioned between the ground and the vine canopy; then the permanent cordon of the grapevine was shaken five times and the arthropods that fell on the beating net were quickly collected with an insect aspirator and stored in a plastic tube $(50 \mathrm{~mL})$ added with $95 \%$ ethanol to prevent predation. Stored material was identified in the laboratory under a dissecting microscope.

\subsubsection{Sweep Net Sampling}

In the first two experiments a sweep net was used to collect the arthropods on groundcover vegetation of the vineyard inter-row. The sweep net, with a diameter of $30 \mathrm{~cm}$, was swept for 10 times in the central inter-row of each plot; for NM plots, the technique was performed in a non-mowed inter-row. The collected arthropods were removed from the net using an insect aspirator and then put into a plastic tube $(50 \mathrm{~mL})$ added with $95 \%$ ethanol. Later, that material was examined in the laboratory under a dissecting microscope for taxa identification.

\subsection{Statistical Analysis}

Data on the abundance of main grapevine pests and natural enemies were analyzed by a general mixed-effects model implemented in R 3.0.2 using the packages "nlme" [22,23]. Prior to the analysis, data were checked for normality and homoscedasticity and the arthropod counts were $\log (n+1)$ transformed, while data on the parasitism rate of leafhopper eggs was arcsine-square root transformed. The assumptions of the models were evaluated by inspecting diagnostic plots of model residuals.

In the experiment on the influence of non-mowed spontaneous vegetation, a linear mixed-effects model (LME) was used to test the effects of treatments (two different grass mowing strategies), vineyard management strategies (conventional vs. organic) and sampling time on arthropods observed/collected with the three different sampling methods. 
In each model, treatment, vineyard management and sampling time were considered as categorical fixed factors. Along with the main effects, all interactions were also tested. To account for the nested design and repeated measures, site identity $(n=4)$ and sampling plot identity $(\mathrm{n}=16)$ were included as random factors.

In the experiment on the influence of different timing of green manure mowing, an LME was used to test the effects of treatments (three different groundcover managements) on arthropods observed/collected throughout the experiment with the different sampling methods. In each model, treatment and sampling time were entered as categorical fixed factors. Along with the main effects all possible interactions were also tested. To account for the repeated measures, sampling plot identity $(n=12)$ was included as a random factor.

In the experiment on the effect of different green manure mixtures, an LME was used to test the effects of treatments (three different mixtures and the control) on arthropods observed on leaf samples during the experiment. In each model, treatment and time were entered as categorical fixed factors. Along with the main effects all possible interactions were also tested. To account for the repeated measures, sampling plot identity $(n=16)$ was included as a random factor.

\section{Results}

In the three experiments, the beating net and sweep net sampling techniques resulted in the collection of a range of beneficial insects such as assassin bugs (Hemiptera: Reduviidae), minute pirate bugs (Hemiptera: Anthocoridae), ground beetles (Coleoptera: Carabidae), coccinellids (Coleoptera: Coccinellidae), hoverflies (Diptera: Syrphidae) predatory thrips (Thysanoptera) and harvestmen (Opiliones); however, they were not considered in the analysis due to their low abundance.

\subsection{Influence of Non-Mowed Spontaneous Vegetation on Arthropod Assemblages}

\subsubsection{Leaf Sampling}

On leaf samples, the density of predatory mites (Phytoseiidae) and non-specialized mites (Tydeidae) was recorded, while phytophagous mites (Tetranychidae) were not observed. Regarding the Phytoseiidae, Kampimodromus aberrans (Oudemans), Amblyseius andersoni (Chant), Typhlodromus pyri Scheuten and Phytoseius finitimus Ribaga were recorded. In organic vineyards $P$. finitimus was the most abundant species, while K. aberrans and T. pyri dominated in conventional ones. Considering this different distribution and their role, predatory mites were analyzed together as a family group. In both the two years of investigation, grass mowing management significantly influenced predatory mite numbers, which were more abundant in NM plots than in FM plots (Table 2; Figure 1). An effect of sampling time was also observed: the density of predatory mites decreased during the time in both years (Table 2; Figure 1).

Table 2. Results of the mixed-effect model testing the effect of mowing strategy, vineyard management, and time of sampling on arthropods observed in leaf samples performed in the experiment on the influence of non-mowed spontaneous vegetation on arthropod assemblages. Asterisk $\left({ }^{*}\right)$ indicate significant effects at $\alpha=0.05$.

\begin{tabular}{|c|c|c|c|c|c|c|c|c|c|}
\hline & \multirow[b]{2}{*}{ Factor or Interaction } & \multicolumn{4}{|c|}{2016} & \multicolumn{4}{|c|}{2017} \\
\hline & & d.f. & $F$ & $P$ & & d.f. & $F$ & $P$ & \\
\hline \multirow{7}{*}{$\begin{array}{c}\text { Predatory mites } \\
\text { (Acari: Phytoseiidae) }\end{array}$} & grass mowing & $1 ; 10$ & 6.863 & 0.026 & * & $1 ; 10$ & 5.359 & 0.043 & * \\
\hline & management & $1 ; 2$ & 0.670 & 0.499 & & $1 ; 2$ & 0.000 & 0.987 & \\
\hline & time & $2 ; 21$ & 5.461 & 0.012 & * & $1 ; 8$ & 6.850 & 0.031 & * \\
\hline & grass mowing:management & $1 ; 10$ & 0.857 & 0.376 & & $1 ; 10$ & 0.849 & 0.378 & \\
\hline & grass mowing:time & $2 ; 21$ & 0.766 & 0.477 & & $1 ; 8$ & 2.181 & 0.178 & \\
\hline & management:time & $2 ; 21$ & 2.923 & 0.076 & & $1 ; 8$ & 0.462 & 0.516 & \\
\hline & grass mowing:management:time & $2 ; 21$ & 1.386 & 0.272 & & $1 ; 8$ & 0.532 & 0.487 & \\
\hline
\end{tabular}


Table 2. Cont.

\begin{tabular}{|c|c|c|c|c|c|c|c|c|}
\hline & \multirow[b]{2}{*}{ Factor or Interaction } & \multicolumn{4}{|c|}{2016} & \multicolumn{3}{|c|}{2017} \\
\hline & & d.f. & $F$ & $P$ & & d.f. & $F$ & $P$ \\
\hline \multirow{7}{*}{$\begin{array}{l}\text { Non-specialized mites } \\
\text { (Acari: Tydeidae) }\end{array}$} & grass mowing & $1 ; 10$ & 0.431 & 0.526 & \multirow{7}{*}{$*$} & $1 ; 10$ & 0.616 & 0.451 \\
\hline & management & $1 ; 2$ & 0.099 & 0.783 & & $1 ; 2$ & 0.102 & 0.780 \\
\hline & time & $2 ; 21$ & 0.451 & 0.643 & & $1 ; 8$ & 3.152 & 0.114 \\
\hline & grass mowing:management & $1 ; 10$ & 1.178 & 0.303 & & $1 ; 10$ & 0.010 & 0.924 \\
\hline & grass mowing:time & $2 ; 21$ & 1.317 & 0.289 & & $1 ; 8$ & 1.679 & 0.231 \\
\hline & management:time & $2 ; 21$ & 3.612 & 0.045 & & $1 ; 8$ & 0.115 & 0.743 \\
\hline & grass mowing:management:time & $2 ; 21$ & 0.568 & 0.575 & & $1 ; 8$ & 0.431 & 0.530 \\
\hline \multirow{7}{*}{$\begin{array}{c}\text { Eggs of lacewings } \\
\text { (Neuroptera: } \\
\text { Chrysopidae) }\end{array}$} & grass mowing & $1 ; 10$ & 0.296 & 0.598 & & $1 ; 10$ & 0.928 & 0.358 \\
\hline & management & $1 ; 2$ & 10.285 & 0.085 & & $1 ; 2$ & 1.141 & 0.397 \\
\hline & time & $2 ; 21$ & 1.450 & 0.257 & & $1 ; 8$ & 1.313 & 0.285 \\
\hline & grass mowing:management & $1 ; 10$ & 0.505 & 0.494 & & $1 ; 10$ & 0.036 & 0.853 \\
\hline & grass mowing:time & $2 ; 21$ & 0.451 & 0.643 & & $1 ; 8$ & 0.001 & 0.997 \\
\hline & management:time & $2 ; 21$ & 0.307 & 0.739 & & $1 ; 8$ & 0.001 & 0.979 \\
\hline & grass mowing:management:time & $2 ; 21$ & 0.284 & 0.755 & & $1 ; 8$ & 0.001 & 0.999 \\
\hline
\end{tabular}

Prior to the analysis, average number of individuals was $\log (n+1)$ transformed.

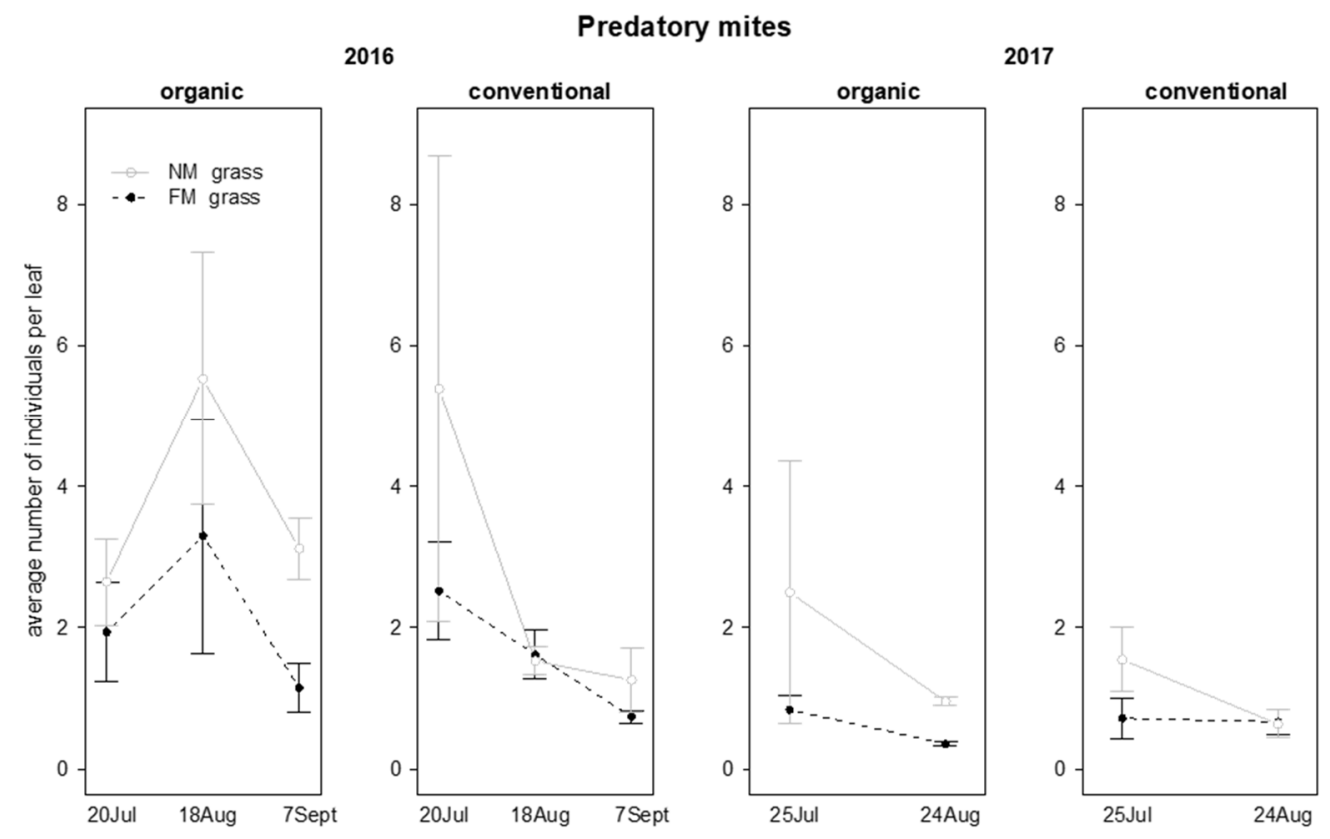

Figure 1. Abundance (mean \pm std. err.) of predatory mites (Acari: Phytoseiidae) on leaf samples during the first experiment in 2016 and 2017.

The abundance of non-specialized mites (Tydeidae) was influenced only by the interaction "vineyard management time" and in 2016 (Table 2); in the first sampling, the Tydeidae were more abundant in conventional than in organic vineyards, and vice versa at the end of August (Figure 2).

Regarding leafhoppers, the presence of Empoasca vitis (Göthe) and Zygina rhamni Ferrari was recorded on leaves. Empoasca vitis abundance was not affected by grass mowing strategies. In 2016, a significant effect of time, and an interaction "vineyard management*time" were found for this pest: it was more abundant in organic than in conventional vineyards and these differences emerged at the end of the observations (Table 3; Figure 3). In the following growing season, leafhopper abundance was significantly affected only by the time (Table 3; Figure 3). 
Tydeid mites
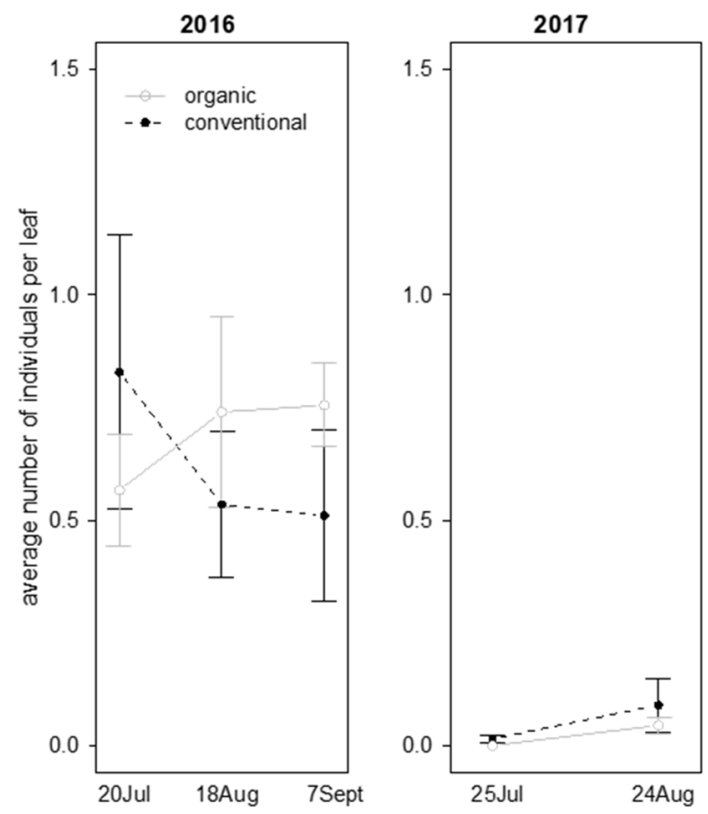

Figure 2. Abundance (mean \pm std. err.) of tydeid mites (Acari: Tydeidae) on leaf samples during the first experiment in 2016 and 2017.

Table 3. Results of the mixed-effect model testing the effect of mowing strategy, vineyard management, and time of sampling on arthropods observed in leaf samples performed in the experiment on the influence of non-mowed spontaneous vegetation on arthropod assemblages. Asterisk $(*)$ indicate significant effects at $\alpha=0.05$.

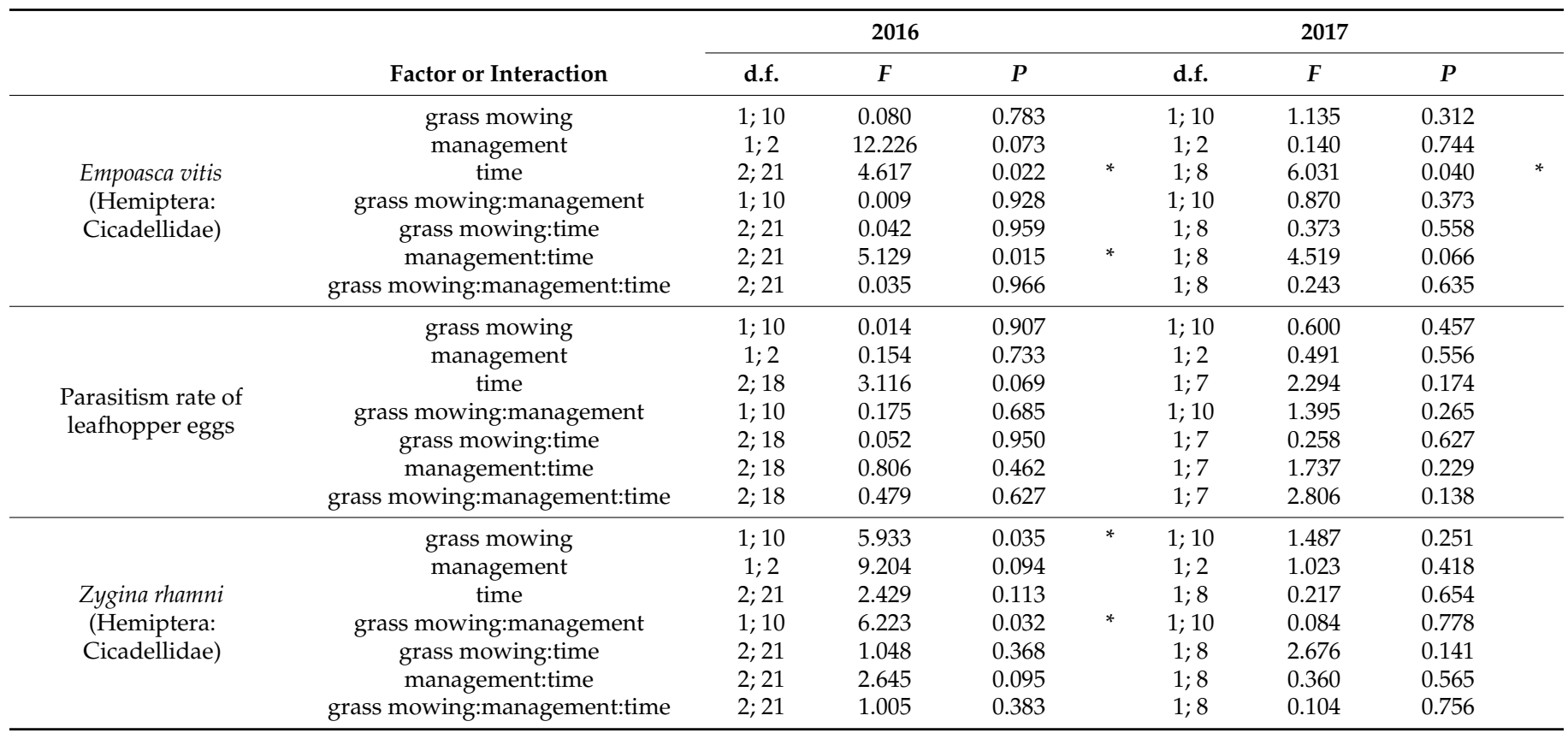

Prior to the analysis, average number of individuals was $\log (n+1)$ transformed while parasitism rate of leafhopper eggs was arcsine-square root transformed. 

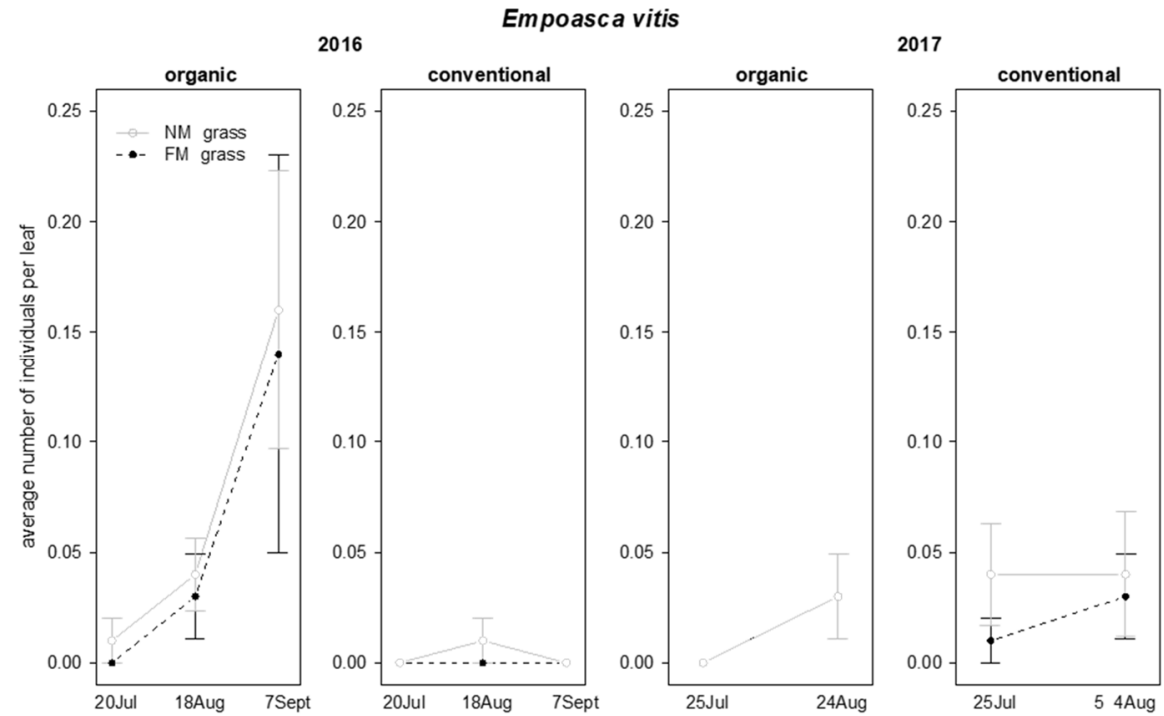

Figure 3. Abundance (mean \pm std. err.) of Empoasca vitis (Hemiptera: Cicadellidae) observed on leaf samples during the first experiment in 2016 and 2017.

The abundance of Z. rhamni in 2016 was significantly influenced by grass mowing and "grass mowing*management interaction", while no significant effects were observed in 2017 (Table 3). In 2016 a higher abundance of Z. rhamni was observed in NM plots than in FM plots in organic vineyards, while no effects were observed in conventional vineyards (Table 3; Figure 4).

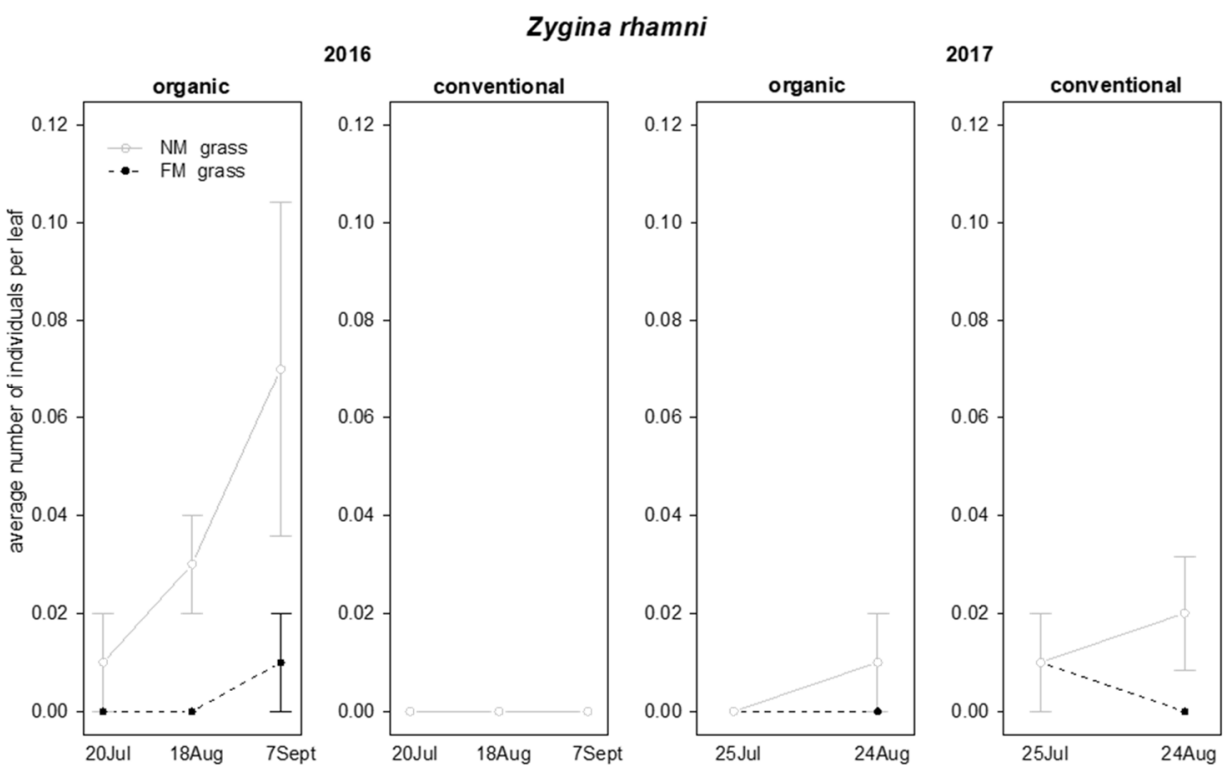

Figure 4. Abundance (mean \pm std. err.) of Zygina rhamni (Hemiptera: Cicadellidae) observed on leaf samples during the first experiment in 2016 and 2017.

In both seasons, the parasitism rate of leafhopper eggs and the abundance of lacewing eggs (Neuroptera: Chrysopidae) were not affected by the investigated factors, including their interactions (Tables 2 and 3).

Finally, the presence of scales, such as Parthenolecanium corni (Bouché) (Hemiptera: Coccidae) and the mealybug $P$. ficus was also recorded, especially in organic vineyards, but at low densities and thus these data were not analyzed. 


\subsubsection{Beating Net Sampling}

The beating net technique allowed to collect additional arthropod species resident on grapevine canopy that were considered in the statistical analysis, in particular: red velvet mites (Acari: Trombidiidae), earwigs (Dermaptera), stink bugs (Hemiptera: Pentatomidae), leafhoppers, larvae of lacewings, and spiders (Araneae).

In 2016, red velvet mites were significantly more abundant on vine canopy in NM plots than in FM plots, showing a decrease along sampling time (Table 4; Figure 5). In 2017, their presence was not analyzed since they were recorded in one vineyard only.

Table 4. Results of the mixed-effect models testing the effect of mowing strategy, vineyard management, and time of sampling on arthropods collected by beating net sampling performed in the experiment on the influence of non-mowed spontaneous vegetation on arthropod assemblages. One asterisk ${ }^{*}$ ) indicate significant effects at $\alpha=0.05$, three asterisks $(* *)$ indicate significant effects at $\alpha=0.001$.

\begin{tabular}{|c|c|c|c|c|c|c|c|c|}
\hline & \multirow[b]{2}{*}{ Factor or Interaction } & \multicolumn{4}{|c|}{2016} & \multicolumn{3}{|c|}{2017} \\
\hline & & d.f. & $F$ & $P$ & & d.f. & $F$ & $P$ \\
\hline \multirow{7}{*}{$\begin{array}{c}\text { Red velvet mites } \\
\text { (Acari: Trombidiidae) }\end{array}$} & grass mowing & $1 ; 10$ & 6.705 & 0.027 & * & & & \\
\hline & management & $1 ; 20$ & 0.035 & 0.869 & & & & \\
\hline & time & $2 ; 21$ & 5.046 & 0.016 & * & & & \\
\hline & grass mowing:management & $1 ; 10$ & 0.400 & 0.541 & & & & \\
\hline & grass mowing:time & $2 ; 21$ & 0.053 & 0.948 & & & & \\
\hline & management:time & $2 ; 21$ & 0.213 & 0.810 & & & & \\
\hline & grass mowing:management:time & $2 ; 21$ & 0.180 & 0.837 & & & & \\
\hline \multirow{7}{*}{$\begin{array}{c}\text { Earwigs } \\
\text { (Dermaptera) }\end{array}$} & grass mowing & $1 ; 10$ & 2.728 & 0.130 & \multirow{4}{*}{$* * *$} & $1 ; 9$ & 0.002 & 0.961 \\
\hline & management & $1 ; 20$ & 12.879 & 0.070 & & $1 ; 2$ & 0.119 & 0.763 \\
\hline & time & $2 ; 21$ & 9.704 & 0.001 & & $1 ; 8$ & 0.011 & 0.918 \\
\hline & grass mowing:management & $1 ; 10$ & 2.279 & 0.162 & & $1 ; 9$ & 0.002 & 0.967 \\
\hline & grass mowing:time & $2 ; 21$ & 3.521 & 0.048 & * & $1 ; 8$ & 0.961 & 0.356 \\
\hline & management:time & $2 ; 21$ & 9.943 & 0.001 & \multirow[t]{2}{*}{$* * *$} & $1 ; 8$ & 0.017 & 0.899 \\
\hline & grass mowing:management:time & $2 ; 21$ & 3.243 & 0.059 & & $1 ; 8$ & 1.549 & 0.249 \\
\hline & grass mowing & $1 ; 10$ & 1.022 & 0.336 & & $1 ; 9$ & 0.072 & 0.794 \\
\hline & management & $1 ; 20$ & 0.979 & 0.427 & & $1 ; 2$ & 0.006 & 0.944 \\
\hline Stink bugs & time & $2 ; 21$ & 0.941 & 0.406 & & $1 ; 8$ & 0.161 & 0.699 \\
\hline (Hemiptera: & grass mowing:management & $1 ; 10$ & 0.935 & 0.356 & & $1 ; 9$ & 0.103 & 0.756 \\
\hline \multirow[t]{3}{*}{ Pentatomidae) } & grass mowing:time & $2 ; 21$ & 0.852 & 0.441 & & $1 ; 8$ & 4.452 & 0.068 \\
\hline & management:time & $2 ; 21$ & 0.902 & 0.421 & & $1 ; 8$ & 0.302 & 0.598 \\
\hline & grass mowing:management:time & $2 ; 21$ & 0.848 & 0.443 & & $1 ; 8$ & 0.091 & 0.771 \\
\hline
\end{tabular}

Prior to the analysis, average number of individuals was $\log (n+1)$ transformed.

The abundance of earwigs observed in 2016 was influenced by time, and the interactions "grass mowing*time" and "vineyard management*time" (Table 4). Their presence in the grape canopy was limited to organic vineyards. At the end of the observations, there were higher numbers of earwigs in FM plots as compared to NM plots (Figure 6). In 2017, the presence of earwigs was not influenced by any of the investigated effects (Table 4; Figure 6).

In both years, the presence of stink bugs was observed on grapevine canopy, but the abundance of this pest was not influenced by the investigated factors and their interactions (Table 4).

In 2016, the abundance of leafhoppers not associated with grapevine was significantly affected by "grass mowing*time" and "time*vineyard management" interactions (Table 5); in NM plots an increasing number of leafhoppers was observed on grapevine canopy during the sampling period, especially in organic vineyards (Figure 7). In contrast, in 2017 , leafhopper abundance was not significantly affected by the investigated factors and their interactions (Table 5). 


\section{Red velvet mites - 2016}
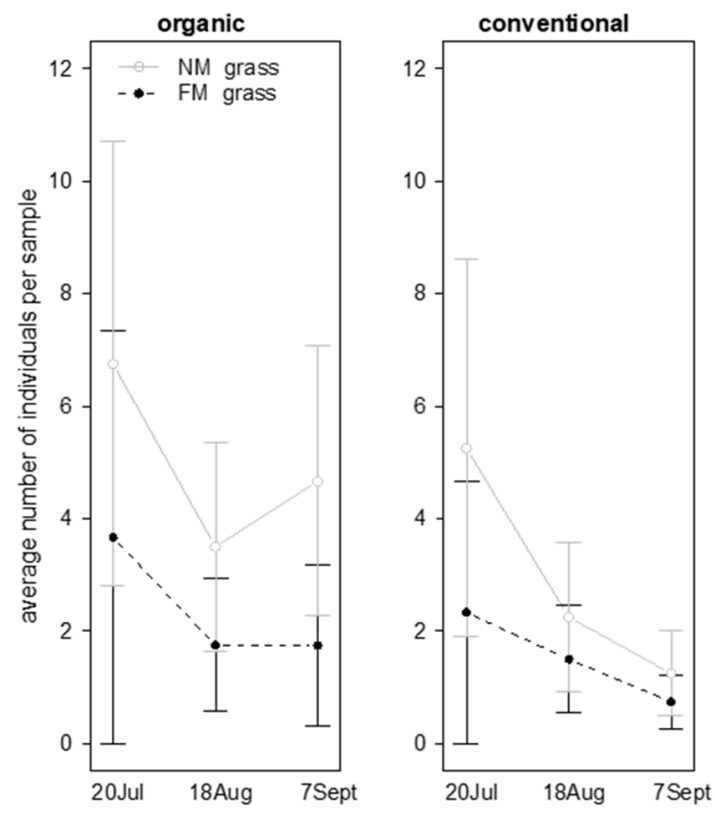

Figure 5. Abundance (mean \pm std. err.) of red velvet mites (Acari: Trombidiidae) sampled by beating net during the first experiment in 2016.

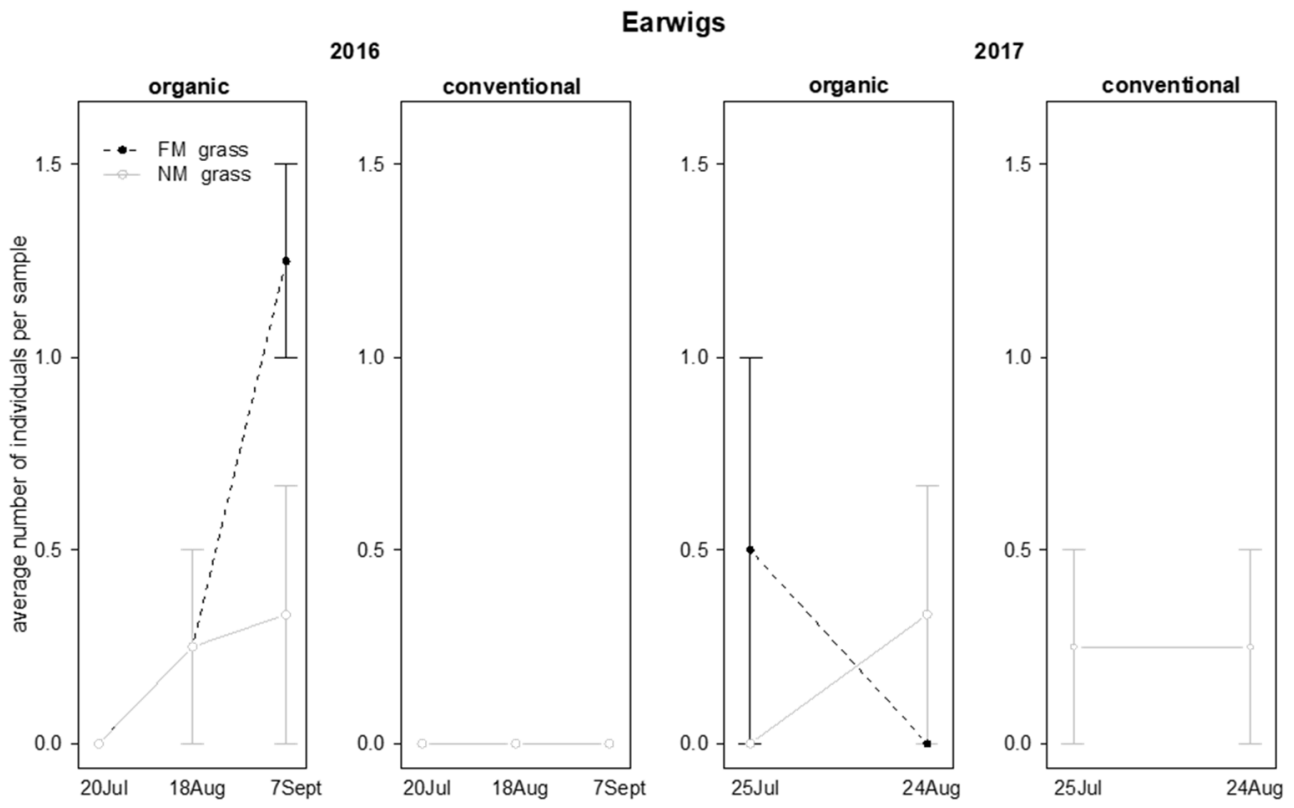

Figure 6. Abundance (mean \pm std. err.) of earwigs (Dermaptera) on beating net samples during the first experiment in 2016 and 2017. 
Table 5. Results of the mixed-effect models testing the effect of mowing strategy, vineyard management, and time of sampling on arthropods collected by beating net sampling performed in the experiment on the influence of non-mowed spontaneous vegetation on arthropod assemblages. One asterisk $\left(^{*}\right)$ indicate significant effects at $\alpha=0.05$, two asterisks $\left(^{* *}\right)$ indicate significant effects at $\alpha=0.01$.

\begin{tabular}{|c|c|c|c|c|c|c|c|c|c|}
\hline & \multirow[b]{2}{*}{ Factor or Interaction } & \multicolumn{4}{|c|}{2016} & \multicolumn{4}{|c|}{2017} \\
\hline & & d.f. & $F$ & $P$ & & d.f. & $F$ & $P$ & \\
\hline \multirow{7}{*}{$\begin{array}{c}\text { Leafhoppers not } \\
\text { associated with } \\
\text { grapevine } \\
\text { (Hemiptera: } \\
\text { Cicadellidae) }\end{array}$} & grass mowing & $1 ; 10$ & 0.288 & 0.603 & \multirow{7}{*}{ * } & $1 ; 9$ & 1.450 & 0.259 & \\
\hline & management & $1 ; 2$ & 0.275 & 0.652 & & $1 ; 2$ & 0.879 & 0.447 & \\
\hline & time & $2 ; 21$ & 1.165 & 0.331 & & $1 ; 8$ & 1.356 & 0.278 & \\
\hline & grass mowing:management & $1 ; 10$ & 1.211 & 0.297 & & $1 ; 9$ & 0.549 & 0.478 & \\
\hline & grass mowing:time & $2 ; 21$ & 3.788 & 0.039 & & $1 ; 8$ & 0.153 & 0.706 & \\
\hline & management:time & $2 ; 21$ & 5.569 & 0.012 & & $1 ; 8$ & 0.017 & 0.900 & \\
\hline & grass mowing:management:time & $2 ; 21$ & 1.204 & 0.320 & & $1 ; 8$ & 2.332 & 0.165 & \\
\hline \multirow{7}{*}{$\begin{array}{c}\text { Larvae of lacewings } \\
\text { (Neuroptera: } \\
\text { Chrysopidae) }\end{array}$} & grass mowing & $1 ; 10$ & 0.082 & 0.781 & \multirow{4}{*}{ * } & $1 ; 9$ & 0.438 & 0.525 & \\
\hline & management & $1 ; 2$ & 0.743 & 0.479 & & $1 ; 2$ & 0.057 & 0.833 & \\
\hline & time & $2 ; 21$ & 3.934 & 0.035 & & $1 ; 8$ & 3.944 & 0.082 & \\
\hline & grass mowing:management & $1 ; 10$ & 0.052 & 0.824 & & $1 ; 9$ & 0.549 & 0.478 & \\
\hline & grass mowing:time & $2 ; 21$ & 0.599 & 0.558 & \multirow{3}{*}{ * } & $1 ; 8$ & 0.609 & 0.458 & \\
\hline & management:time & $2 ; 21$ & 4.167 & 0.030 & & $1 ; 8$ & 0.001 & 0.981 & \\
\hline & grass mowing:management:time & $2 ; 21$ & 0.630 & 0.543 & & $1 ; 8$ & 0.964 & 0.355 & \\
\hline \multirow{7}{*}{$\begin{array}{c}\text { Spiders } \\
\text { (Araneae) }\end{array}$} & grass mowing & $1 ; 10$ & 0.236 & 0.638 & \multirow{3}{*}{ * } & $1 ; 9$ & 1.246 & 0.293 & \\
\hline & management & $1 ; 2$ & 22.547 & 0.042 & & $1 ; 2$ & 12.007 & 0.074 & \\
\hline & time & $2 ; 21$ & 0.910 & 0.418 & & $1 ; 8$ & 0.027 & 0.874 & \\
\hline & grass mowing:management & $1 ; 10$ & 2.825 & 0.124 & \multirow{4}{*}{$\begin{array}{l}* \\
* *\end{array}$} & $1 ; 9$ & 1.436 & 0.261 & \\
\hline & grass mowing:time & $2 ; 21$ & 3.564 & 0.047 & & $1 ; 8$ & 0.349 & 0.571 & \\
\hline & management:time & $2 ; 21$ & 5.822 & 0.010 & & $1 ; 8$ & 6.341 & 0.036 & * \\
\hline & grass mowing:management:time & $2 ; 21$ & 0.862 & 0.437 & & $1 ; 8$ & 0.253 & 0.628 & \\
\hline
\end{tabular}

Prior to the analysis, average number of individuals was $\log (n+1)$ transformed.
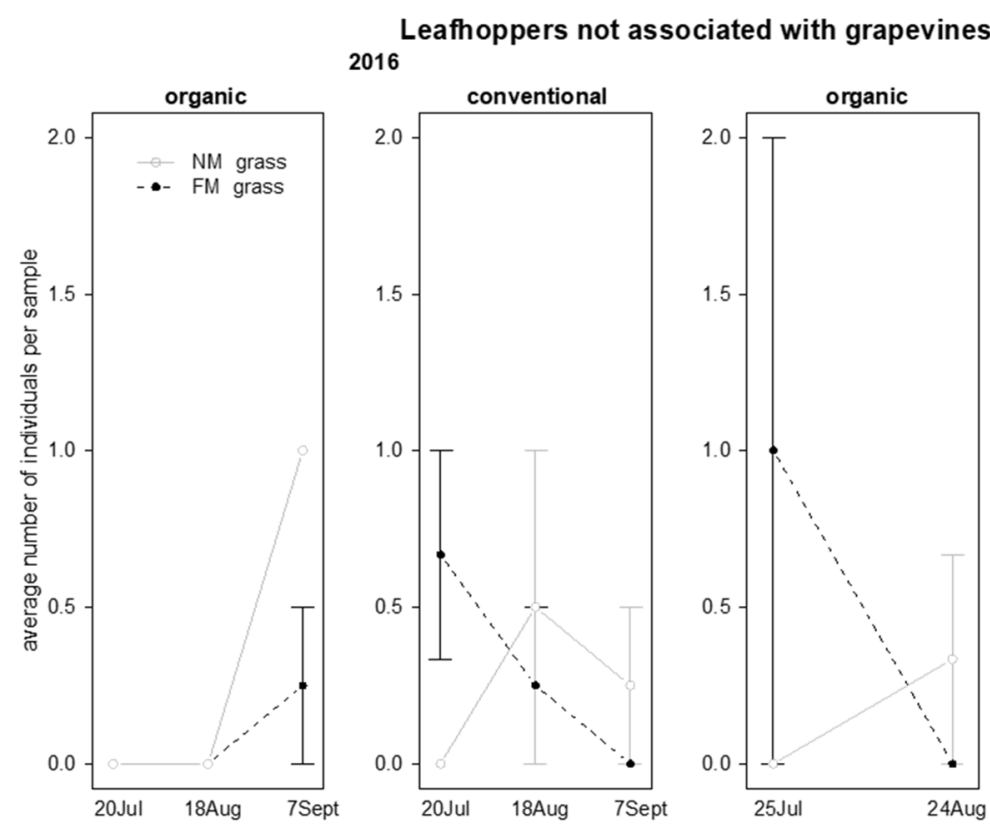

2017

Figure 7. Abundance (mean \pm std. err.) of leafhoppers (Hemiptera: Cicadellidae) not associated with grapevines on beating net samples during the first experiment in 2016 and 2017.

In 2016, the abundance of lacewing larvae was influenced by time and interaction "time*vineyard management": these predators were observed only in organic vineyards and their abundance decreased during the season (Table 5; Figure 8). In 2017, their abundance was not significantly affected by the investigated factors (Table 5; Figure 8). 


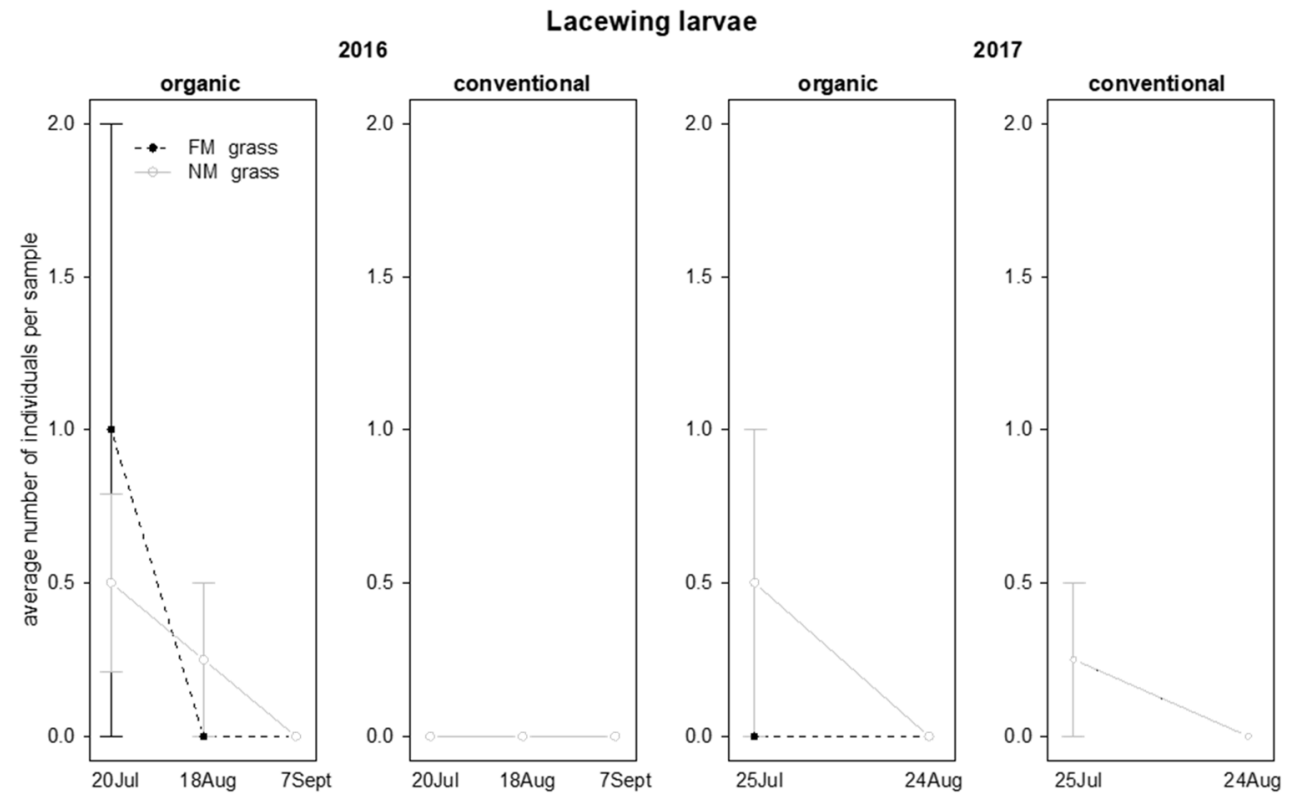

Figure 8. Abundance (mean \pm std. err.) of lacewing larvae (Neuroptera: Chrysopidae) on beating net samples during the first experiment in 2016 and 2017.

In 2016, the abundance of spiders was influenced by vineyard management and by the interactions "vineyard management"time" and "grass mowing*time". Higher spider numbers were reached in organic vineyards in comparison with conventional ones (Table 5; Figure 9). In the same period spider abundance increased in NM plots but not in FM plots (Table 5; Figure 9). In 2017, the spider density was influenced by the interaction "time* vineyard management", resulting with greater abundance in organic than in conventional vineyards on the first sampling date only (Table 5; Figure 9).

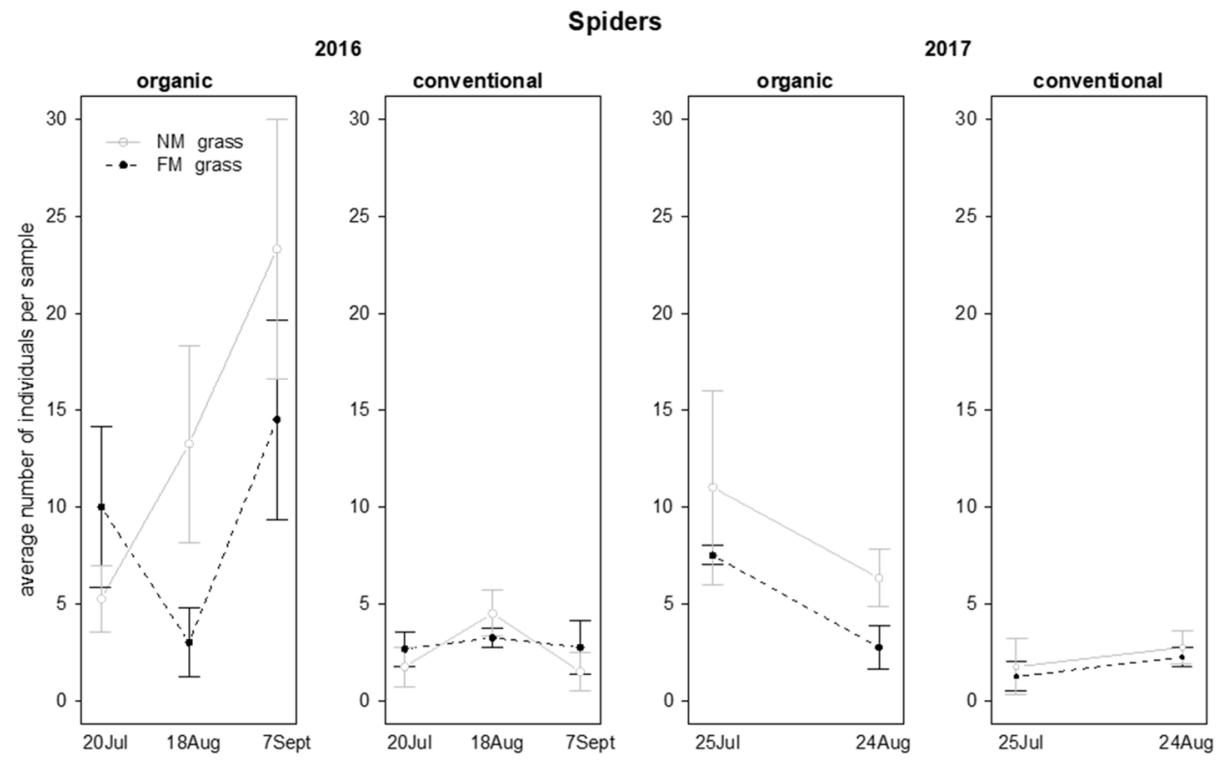

Figure 9. Abundance (mean \pm std. err.) of spiders (Araneae) on beating net samples during the first experiment in 2016 and 2017.

\subsubsection{Sweep Net Sampling}

During the investigation, the presence of leafhoppers, nabids (Hemiptera: Nabidae), assassin bugs, lacewing larvae, parasitic wasps (Hymenoptera), and spiders was recorded in vineyard inter-row groundcover and were considered in the statistical analysis. 
The abundance of leafhoppers not associated with grapevine, in the two years of investigation, was influenced by time, showing a significant increase during the sampling period (Table 6; Figure 10), and in 2017 also by the interactions "grass mowing*vineyard management" and "vineyard management*time". In the second year of investigation, leafhoppers were more abundant in FM plots in organic vineyards and in NM plots in conventional ones (Table 6; Figure 10). Moreover, the leafhoppers' abundance increased during the sampling period in organic vineyards, while it remained at constant levels in conventional ones (Table 6; Figure 10).

Table 6. Results of the mixed-effect model testing the effect of mowing strategy, vineyard management and time of sampling on arthropods collected through the sweep net sampling performed in the experiment on the influence of non-mowed spontaneous vegetation on arthropod assemblages. One asterisk $\left(^{*}\right)$ indicate significant effects at $\alpha=0.05$, two asterisks $\left(^{* *}\right)$ indicate significant effects at $\alpha=0.01$.

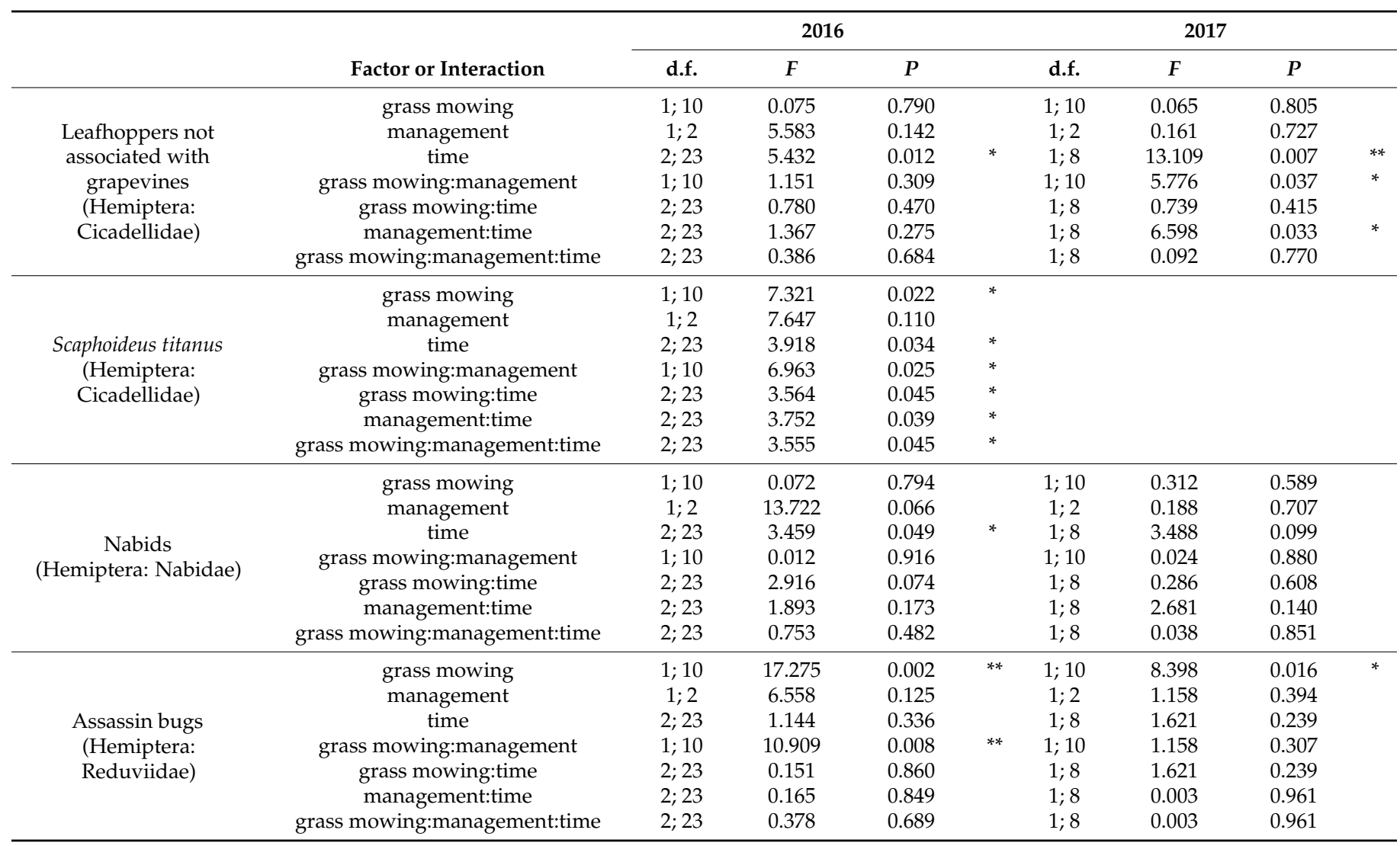

Prior to the analysis average number of individuals was $\log (n+1)$ transformed.

Adults of $S$. titanus were found only in 2016. Their abundance was significantly affected by grass mowing, time, and interactions "grass mowing*time", "grass mowing*vineyard management", vineyard management*time", and "grass mowing*vineyard management*time" (Table 6). Scaphoideus titanus was recorded only in NM plots in organic vineyards and its abundance increased during the sampling period (Figure 11). No adults of S. titanus were observed in 2017.

The presence of nabids was not significantly affected by investigated factors in this study (i.e., grass mowing and vineyard management), but only by the time in 2016 (Table 6).

The presence of assassin bugs was influenced by grass mowing, and in 2016 also by the interaction "grass mowing*vineyard management" (Table 6; Figure 12). A higher number of assassin bugs was observed in NM plots compared to FM plots, but in 2016 this effect emerged only in conventional vineyards (Table 6; Figure 12). 


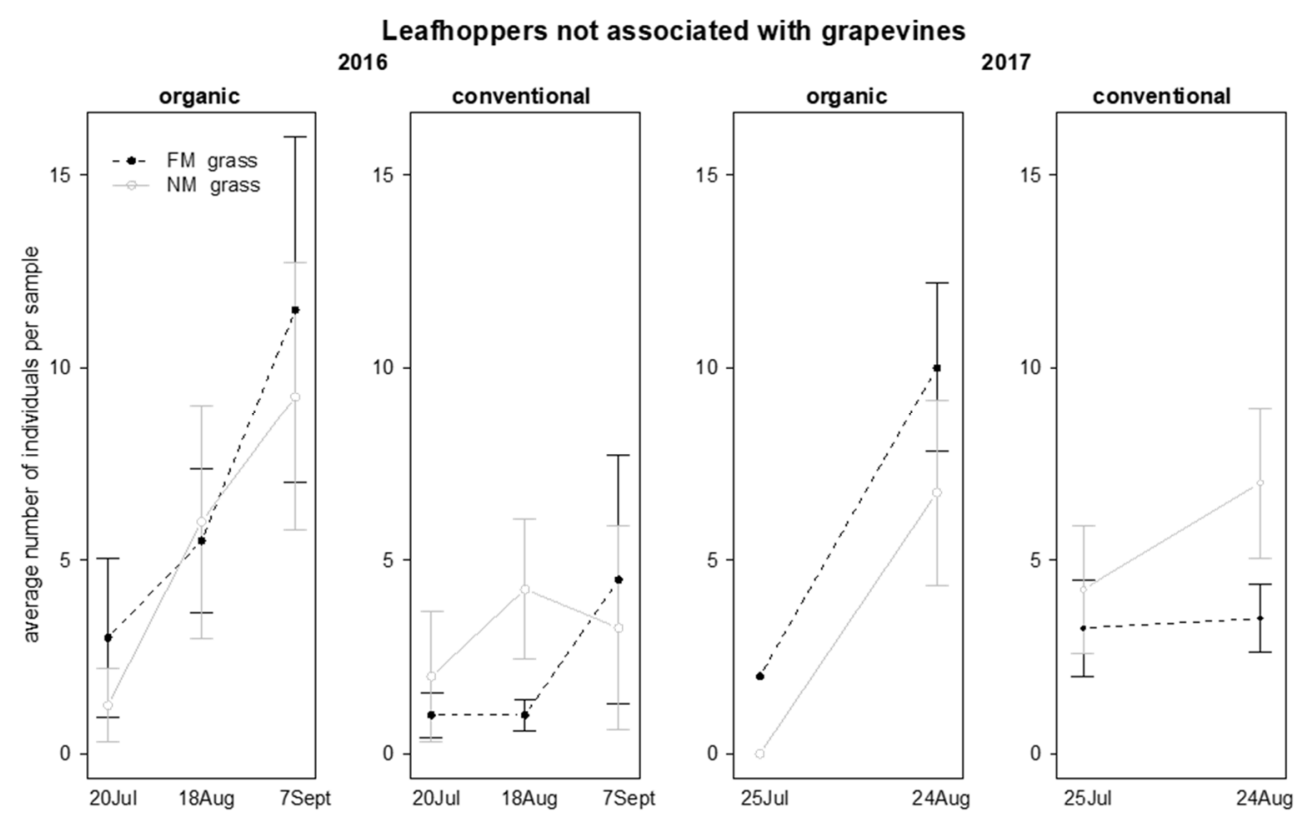

Figure 10. Abundance (mean \pm std. err.) of leafhoppers (Hemiptera: Cicadellidae) not associated with grapevine observed on sweep net samples during the first experiment in 2016 and 2017.

Scaphoideus titanus adults - 2016
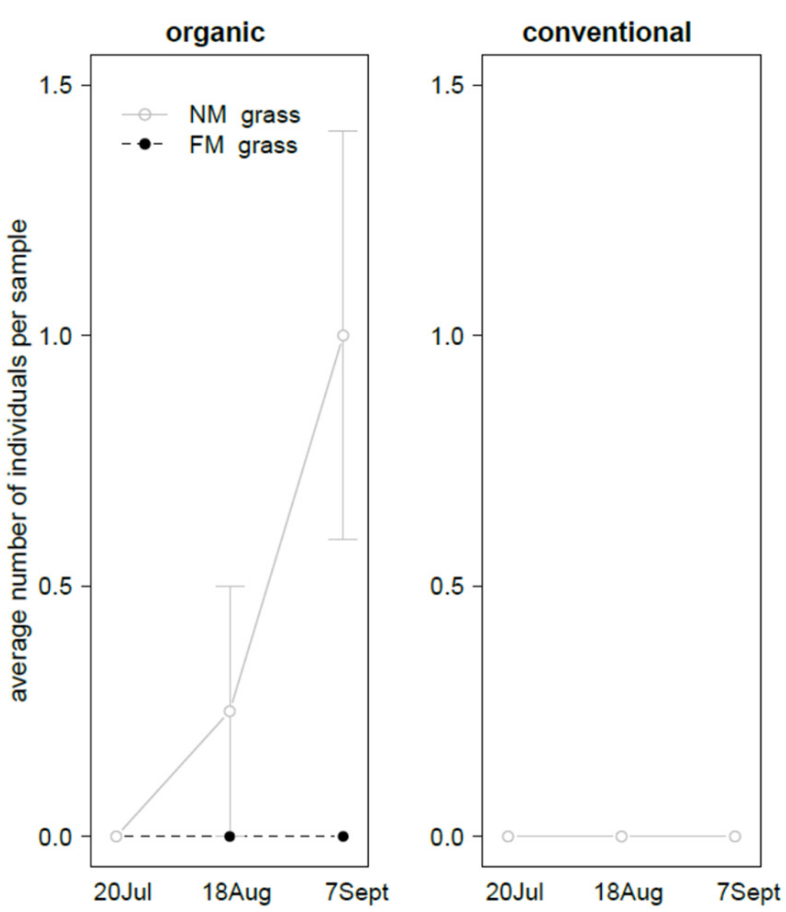

Figure 11. Abundance (mean \pm std. err.) of Scaphoideus titanus (Hemiptera: Cicadellidae) adults found in sweep net samples during the first experiment in 2016. 


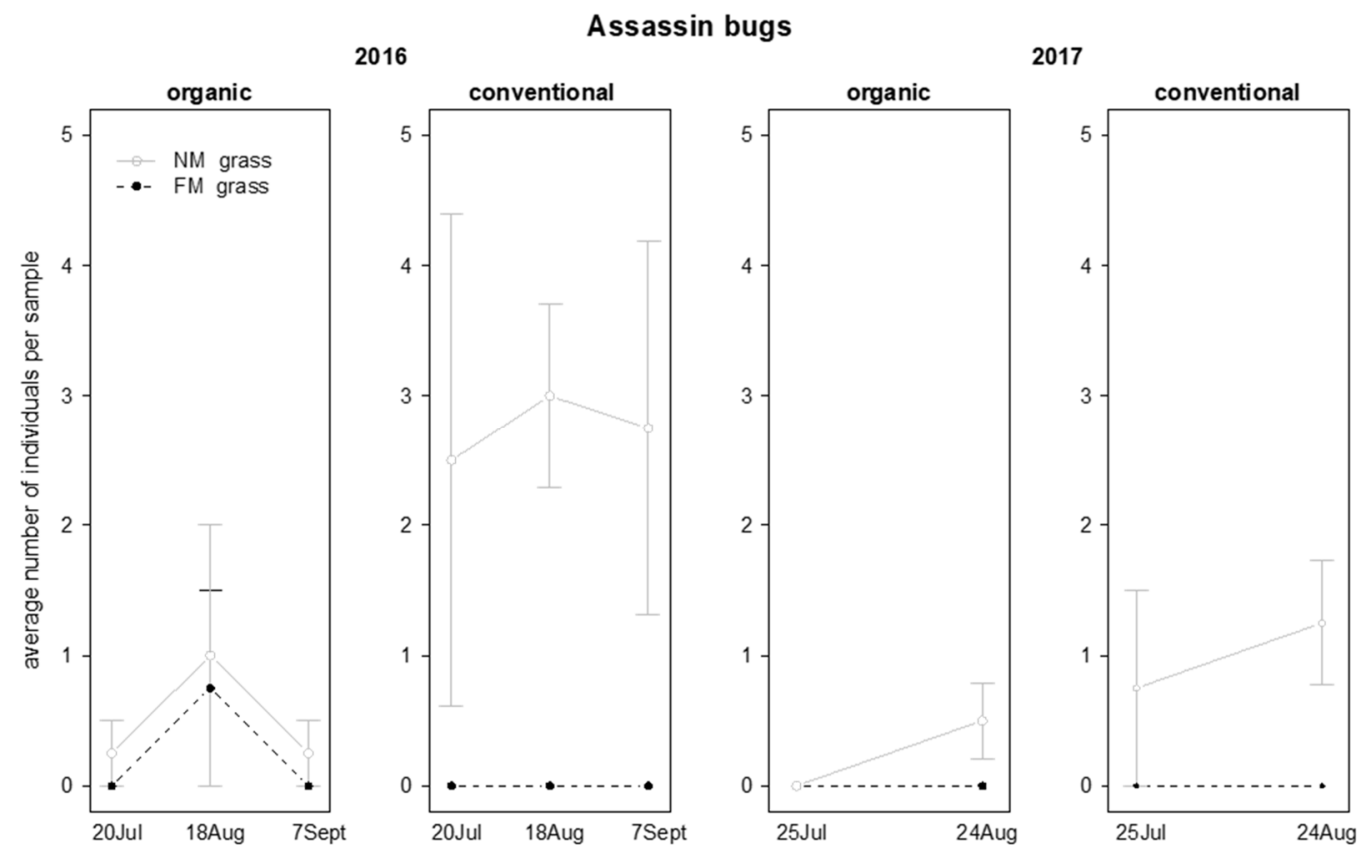

Figure 12. Abundance (mean \pm std. err.) of assassin bugs (Hemiptera: Reduviidae) observed on sweep net samples during the first experiment in 2016 and 2017.

The presence of lacewing larvae was not significantly affected by the investigated factors in this study, except by time in 2016 (Table 7).

Table 7. Results of the mixed-effect model testing the effect of mowing strategy, vineyard management and time of sampling on arthropods collected through the sweep net sampling performed in the experiment on the influence of non-mowed spontaneous vegetation on arthropod assemblages. One asterisk $\left(^{*}\right)$ indicate significant effects at $\alpha=0.05$, two asterisks $\left({ }^{* *}\right)$ indicate significant effects at $\alpha=0.01$, three asterisks $\left.{ }^{* * *}\right)$ indicate significant effects at $\alpha=0.001$.

\begin{tabular}{|c|c|c|c|c|c|c|c|c|c|}
\hline & \multirow[b]{2}{*}{ Factor or Interaction } & \multicolumn{4}{|c|}{2016} & \multicolumn{4}{|c|}{2017} \\
\hline & & d.f. & $F$ & $P$ & & d.f. & $F$ & $P$ & \\
\hline \multirow{7}{*}{$\begin{array}{l}\text { Lacewing larvae } \\
\text { (Neuroptera: } \\
\text { Chrysopidae) }\end{array}$} & grass mowing & $1 ; 10$ & 0.730 & 0.413 & \multirow{7}{*}{$* * *$} & $1 ; 10$ & 2.093 & 0.179 & \\
\hline & management & $1 ; 2$ & 0.004 & 0.957 & & $1 ; 2$ & 0.770 & 0.473 & \\
\hline & time & $2 ; 23$ & 14.774 & $<0.001$ & & $1 ; 8$ & 0.000 & 1.000 & \\
\hline & grass mowing:management & $1 ; 10$ & 0.484 & 0.503 & & $1 ; 10$ & 1.570 & 0.239 & \\
\hline & grass mowing:time & $2 ; 23$ & 0.520 & 0.601 & & $1 ; 8$ & 0.000 & 1.000 & \\
\hline & management:time & $2 ; 23$ & 0.036 & 0.965 & & $1 ; 8$ & 0.000 & 1.000 & \\
\hline & grass mowing:management:time & $2 ; 23$ & 0.562 & 0.578 & & $1 ; 8$ & 0.000 & 1.000 & \\
\hline \multirow{7}{*}{$\begin{array}{c}\text { Parasitic wasps } \\
\text { (Hymenoptera Apocrita } \\
\text { Terebrantia) }\end{array}$} & grass mowing & $1 ; 10$ & 4.023 & 0.073 & \multirow{7}{*}{ * } & $1 ; 10$ & 7.500 & 0.021 & * \\
\hline & management & $1 ; 2$ & 4.205 & 0.177 & & $1 ; 2$ & 7.322 & 0.114 & \\
\hline & time & $2 ; 23$ & 2.190 & 0.135 & & $1 ; 8$ & 0.428 & 0.531 & \\
\hline & grass mowing:management & $1 ; 10$ & 2.367 & 0.155 & & $1 ; 10$ & 0.010 & 0.923 & \\
\hline & grass mowing:time & $2 ; 23$ & 3.421 & 0.050 & & $1 ; 8$ & 5.169 & 0.053 & . \\
\hline & management:time & $2 ; 23$ & 2.931 & 0.074 & & $1 ; 8$ & 2.531 & 0.150 & \\
\hline & grass mowing:management:time & $2 ; 23$ & 0.594 & 0.560 & & $1 ; 8$ & 0.863 & 0.380 & \\
\hline \multirow{7}{*}{$\begin{array}{c}\text { Spiders } \\
\text { (Araneae) }\end{array}$} & grass mowing & $1 ; 10$ & 11.773 & 0.006 & \multirow[t]{7}{*}{ ** } & $1 ; 10$ & 11.802 & 0.006 & \multirow[t]{7}{*}{ ** } \\
\hline & time & $2 ; 23$ & 1.917 & 0.170 & & $1 ; 2$ & 2.189 & 0.277 & \\
\hline & management & $1 ; 2$ & 1.525 & 0.342 & & $1 ; 8$ & 0.004 & 0.950 & \\
\hline & grass mowing:time & $2 ; 23$ & 4.860 & 0.017 & & $1 ; 10$ & 0.152 & 0.705 & \\
\hline & grass mowing:management & $1 ; 10$ & 1.425 & 0.260 & & $1 ; 8$ & 0.805 & 0.396 & \\
\hline & time:management & $2 ; 23$ & 0.086 & 0.918 & & $1 ; 8$ & 0.776 & 0.404 & \\
\hline & grass mowing:time:management & $2 ; 23$ & 0.883 & 0.427 & & $1 ; 8$ & 1.660 & 0.234 & \\
\hline
\end{tabular}

Prior to the analysis average number of individuals was $\log (n+1)$ transformed.

In 2016, the abundance of parasitic wasps was influenced by the interaction "grass mowing*time" (Table 7): their presence increased in some sampling dates but only in NM plots (Figure 13). A marginal difference, close to the significance level $(P=0.073)$, was 
detected for grass mowing. In 2017, the abundance of parasitic wasps was significantly influenced by grass mowing, being higher in NM plots than FM plots (Table 7; Figure 13).

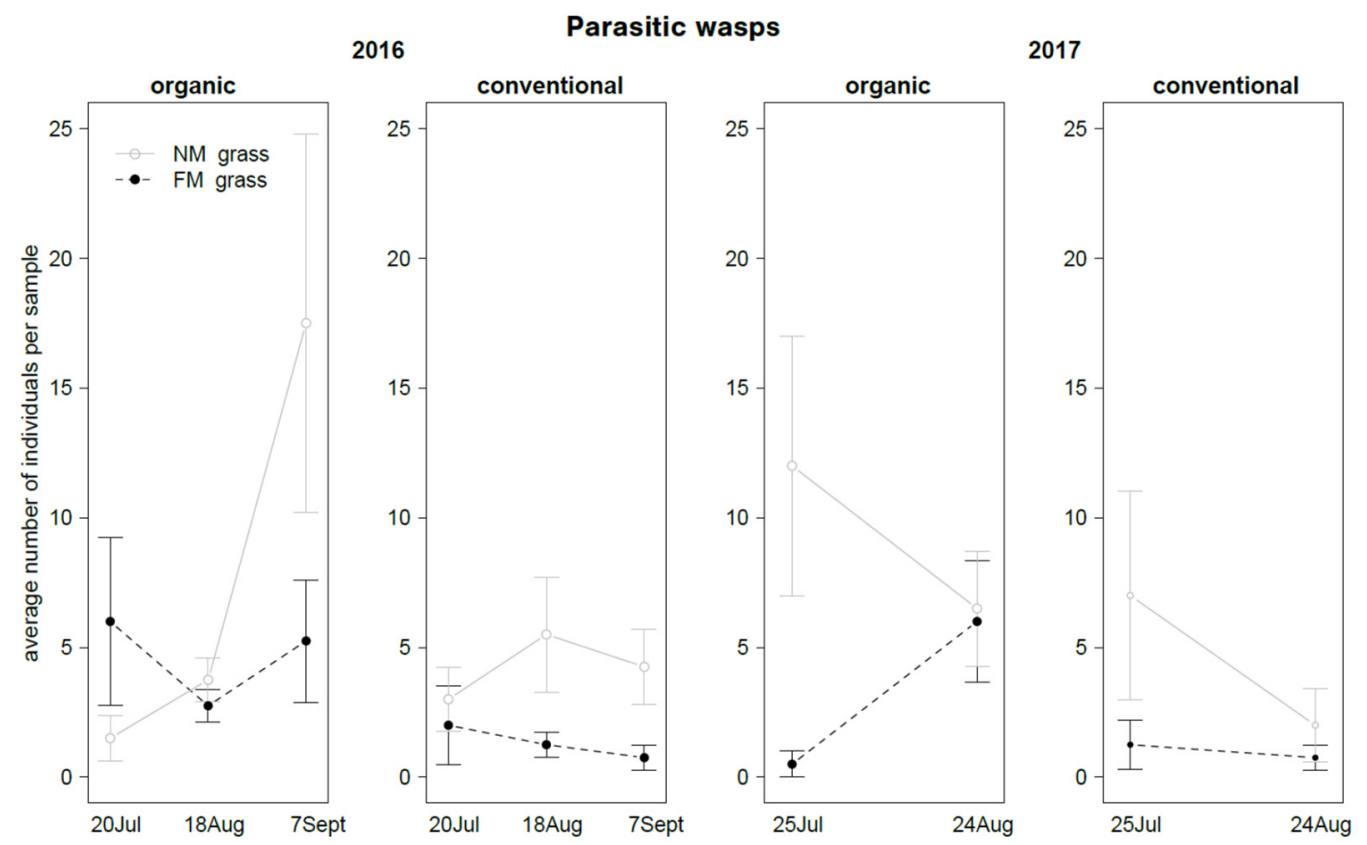

Figure 13. Abundance (mean \pm std. err.) of parasitic wasps (Hymenoptera Apocrita Terebrantia) observed on sweep net samples during the first experiment in 2016 and 2017.

Spiders were more abundant in NM plots than in FM plots in both years (Table 7; Figure 14). Additionally, in 2016 their presence was also influenced by the "grass mowing*time" interaction because spider number increased during the experiment in NM plots, while showed different trends in FM plots (Table 7; Figure 14).

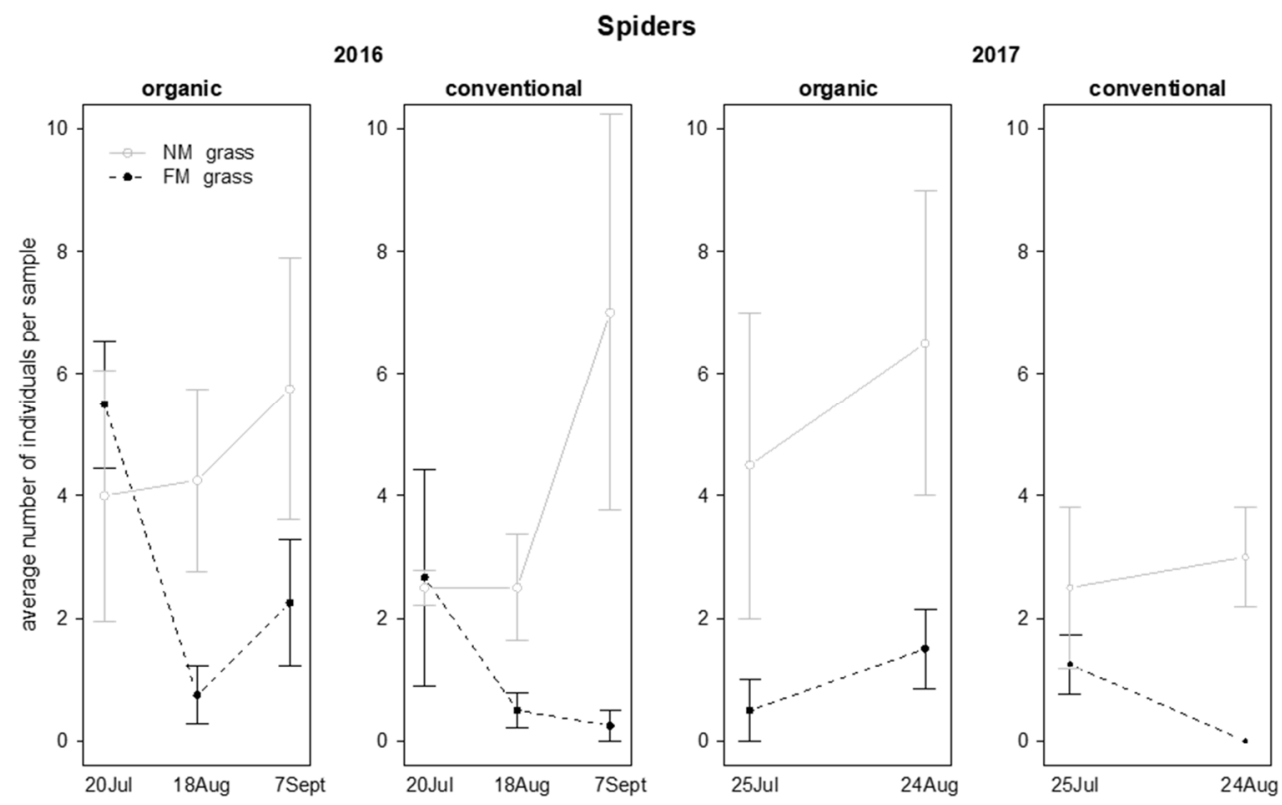

Figure 14. Abundance (mean \pm std. err.) of spiders (Araneae) observed on sweep net samples during the first experiment in 2016 and 2017. 


\subsection{Influence of Different Timing of Green Manure Mowing \\ 3.2.1. Leaf Sampling}

The presence of the phytophagous mite Panonychus ulmi (Koch) and of two species of predatory mites (P. finitimus and T. pyri) was observed on leaf samples. Predatory mites were analyzed together as a family group. The abundance of $P$. ulmi was significantly affected by the sampling time and the interaction "treatment*time" (Table 8). During the sampling period, the abundance of $P$. ulmi increased in the control plots, while it remained at low levels in both of the green manure plots (Figure 15). Predatory mites were not significantly affected by the different groundcover management, only by the sampling time (Table 8; Figure 16).

Table 8. Results of the mixed-effect model testing the effect of treatment and time of sampling on arthropods on leaf sampling performed in the experiment on the influence of different timing of a green manure mowing. One asterisk $\left.{ }^{*}\right)$ indicates significant effects at $\alpha=0.05$, two asterisks $\left(^{* *}\right)$ indicate significant effects at $\alpha=0.01$, three asterisks $\left(^{* * *}\right)$ indicate significant effects at $\alpha=0.001$.

\begin{tabular}{|c|c|c|c|c|c|}
\hline & Factor or Interaction & d.f. & $F$ & $P$ & \\
\hline \multirow{3}{*}{$\begin{array}{c}\text { Predatory mites } \\
\text { (Acari: Phytoseiidae) }\end{array}$} & treatment & $2 ; 9$ & 1.222 & 0.339 & \multirow{3}{*}{ * } \\
\hline & time & $2 ; 18$ & 3.602 & 0.048 & \\
\hline & treatment:time & $4 ; 18$ & 1.517 & 0.239 & \\
\hline \multirow{3}{*}{$\begin{array}{l}\text { Eggs of predatory mites } \\
\text { (Acari: Phytoseiidae) }\end{array}$} & treatment & $2 ; 9$ & 4.554 & 0.043 & \multirow[t]{3}{*}{ * } \\
\hline & time & $2 ; 18$ & 0.380 & 0.689 & \\
\hline & treatment:time & $4 ; 18$ & 0.050 & 0.995 & \\
\hline \multirow{3}{*}{$\begin{array}{c}\text { Panonychus ulmi } \\
\text { (Acari: Tetranychidae) }\end{array}$} & treatment & $2 ; 9$ & 3.594 & 0.071 & \multirow{3}{*}{ ** } \\
\hline & time & $2 ; 18$ & 6.505 & 0.008 & \\
\hline & treatment:time & $4 ; 18$ & 4.010 & 0.017 & \\
\hline \multirow{3}{*}{$\begin{array}{l}\text { Eggs of Panonychus ulmi } \\
\text { (Acari: Tetranychidae) }\end{array}$} & treatment & $2 ; 9$ & 6.572 & 0.017 & $*$ \\
\hline & time & $2 ; 18$ & 7.044 & 0.006 & $* *$ \\
\hline & treatment:time & $4 ; 18$ & 6.573 & 0.002 & ** \\
\hline & treatment & $2 ; 9$ & 0.951 & 0.422 & \multirow{3}{*}{ *** } \\
\hline $\begin{array}{c}\text { Empoasca vitls } \\
\text { (Hemintera. Cicadellidae) }\end{array}$ & time & $2 ; 18$ & 49.937 & $<0.0001$ & \\
\hline ( Hemptera: cicademade) & treatment:time & $4 ; 18$ & 0.908 & 0.480 & \\
\hline \multirow{3}{*}{$\begin{array}{c}\text { Zygina rhamni } \\
\text { (Hemiptera: Cicadellidae) }\end{array}$} & treatment & $2 ; 9$ & 0.049 & 0.952 & \multirow{3}{*}{$* *$} \\
\hline & time & $2 ; 18$ & 6.203 & 0.009 & \\
\hline & treatment:time & $4 ; 18$ & 0.885 & 0.493 & \\
\hline \multirow{3}{*}{$\begin{array}{c}\text { Lacewing eggs } \\
\text { (Neuroptera: Chrysopidae) }\end{array}$} & treatment & $2 ; 9$ & 1.619 & 0.251 & \\
\hline & time & $2 ; 18$ & 0.670 & 0.524 & \\
\hline & treatment:time & $4 ; 18$ & 0.569 & 0.689 & \\
\hline \multirow{3}{*}{$\begin{array}{l}\text { Parthenolecanium corni } \\
\text { (Hemiptera: Coccidae) }\end{array}$} & treatment & $2 ; 9$ & 0.545 & 0.598 & \multirow{3}{*}{$* * *$} \\
\hline & time & $2 ; 18$ & 28.253 & $<0.0001$ & \\
\hline & treatment:time & $4 ; 18$ & 0.915 & 0.476 & \\
\hline
\end{tabular}

Prior to the analysis average number of individuals was $\log (n+1)$ transformed. 
Panonychus uImi

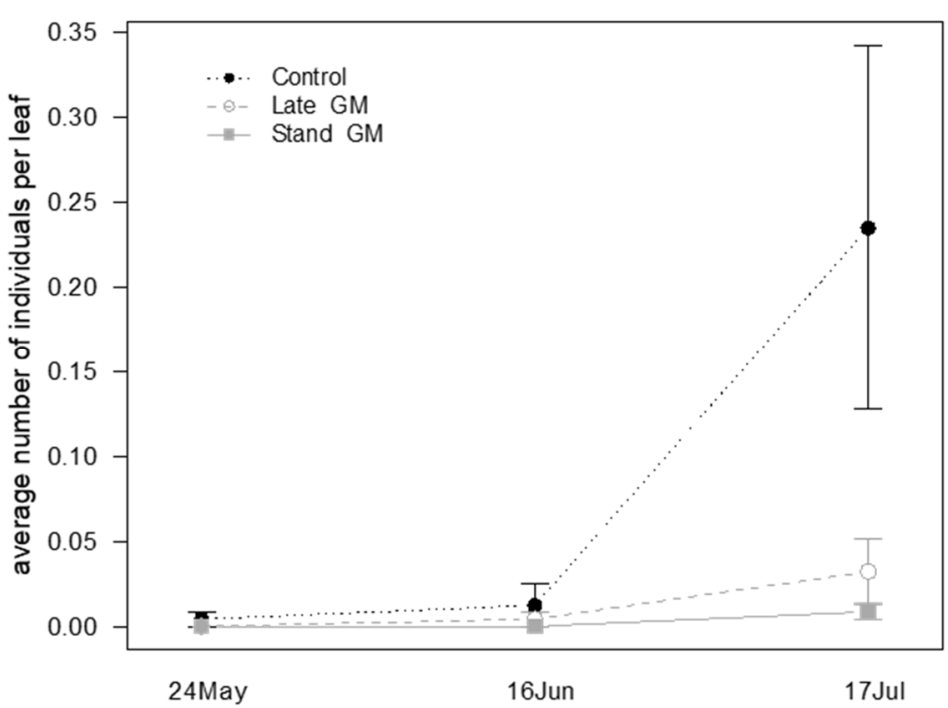

Figure 15. Abundance (mean \pm std. err.) of Panonychus ulmi (Acari: Tetranychidae) observed on leaf samples during the second experiment in 2017.

\section{Predatory mites}

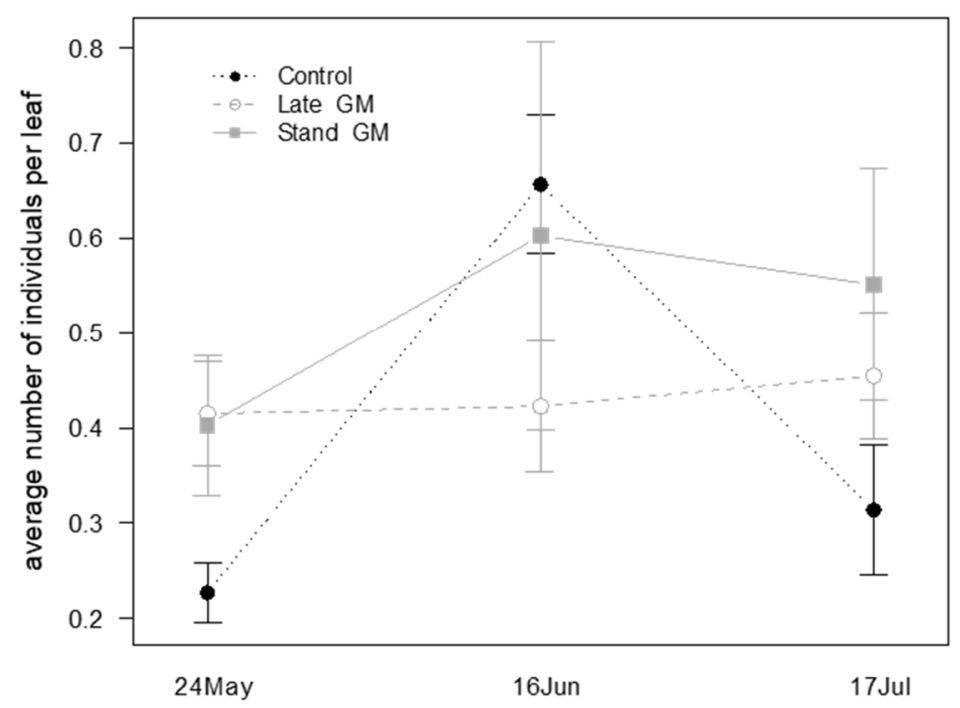

Figure 16. Abundance (mean \pm std. err.) of predatory mites (Acari: Phytoseiidae) observed on leaf samples during the second experiment in 2017.

Regarding leafhoppers, the abundance of E. vitis and Z. rhamni on leaves was significantly affected only by the sampling time (Table 8). Finally, no effects emerged on the abundance of lacewing eggs, while P. corni densities were affected only by sampling time (Table 8).

\subsubsection{Beating Net Sampling}

Using the beating net technique, several leafhoppers, stink bugs, red velvet mites, and spiders were recorded and considered in the statistical analysis. The abundance of leafhoppers and stink bugs was not influenced by the investigated factors, including their interactions (Table 9). 
Table 9. Results of the mixed-effect model testing the effect of treatment and time of sampling on arthropods on beating net sampling performed in the experiment on the influence of different timing of a green manure mowing. One asterisk $\left.{ }^{*}\right)$ indicates significant effects at $\alpha=0.05$, three asterisks ${ }^{(* * *}$ ) indicate significant effects at $\alpha=0.001$.

\begin{tabular}{ccccc}
\hline & Factor or Interaction & d.f. & $\boldsymbol{F}$ & $\boldsymbol{P}$ \\
\hline Leafhoppers not associated with grapevines & treatment & $2 ; 9$ & 1.789 & 0.222 \\
(Hemiptera: Cicadellidae) & time & $2 ; 18$ & 1.789 & 0.196 \\
& treatment:time & $4 ; 18$ & 0.963 & 0.452 \\
Stink bugs & treatment & $2 ; 9$ & 1.356 & 0.306 \\
& time & $2 ; 18$ & 1.656 & 0.219 \\
(Hemiptera: Pentatomidae) & treatment:time & $4 ; 18$ & 0.436 & 0.781 \\
\hline Red velvet mites & treatment & $2 ; 9$ & 2.509 & 0.136 \\
(Acari: Trombidiidae) & time & $2 ; 18$ & 5.856 & 0.011 \\
& treatment:time & $4 ; 18$ & 1.971 & 0.142 \\
Ladybirds & treatment & $2 ; 9$ & 1.000 & 0.405 \\
(Coleoptera: Coccinellidae) & time & $2 ; 18$ & 1.000 & 0.387 \\
Spiders & treatment:time & $4 ; 18$ & 1.000 & 0.433 \\
(Araneae) & treatment & $2 ; 9$ & 0.694 & 0.525 \\
& time & $2 ; 18$ & 12.828 & 0.0003 \\
& treatment:time & $4 ; 18$ & 3.436 & 0.030 \\
\hline
\end{tabular}

Prior to the analysis average number of individuals was $\log (n+1)$ transformed.

Among beneficial arthropods, the abundance of red velvet mites was significantly affected only by the sampling time, showing a tendency to increase in Late-GM plots, although this difference was non-significant (Table 9; Figure 17). In contrast, the abundance of ladybird adults did not show any difference among the investigated factors and their interactions (Table 9).

\section{Red velvet mites}

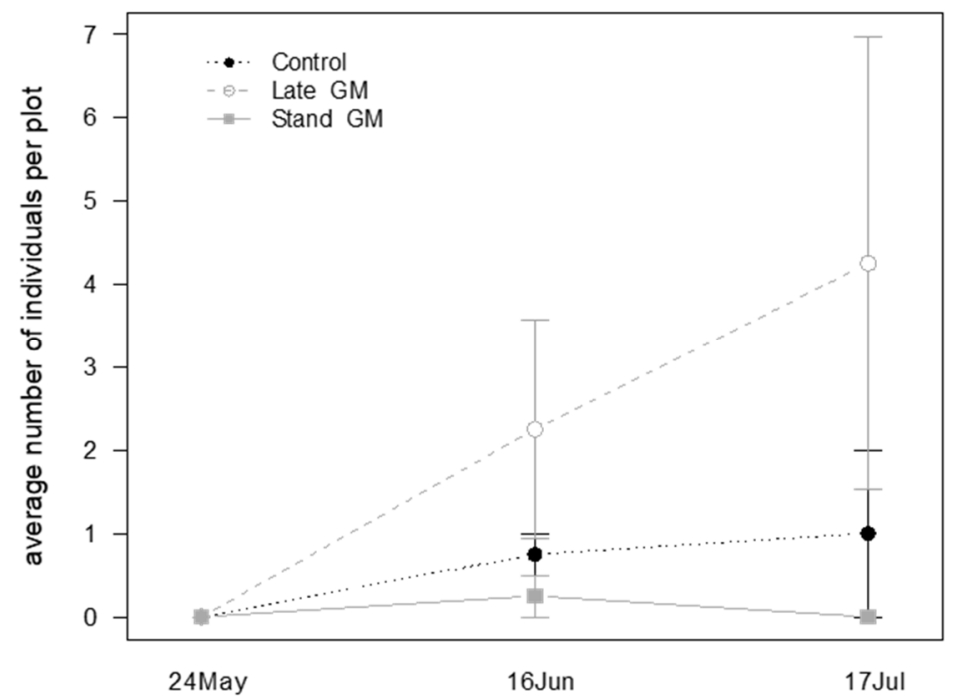

Figure 17. Abundance (mean \pm std. err.) of red velvet mites (Acari: Trombidiidae) observed on beating net samples during the second experiment in 2017.

The management of inter-row groundcover influenced the presence of spiders during the sampling time (Table 9); in the last sampling date they were more abundant in Late-GM and in Control plots than in Stand-GM plots $(P=0.026$ and $P=0.039$, respectively; Figure 18). 


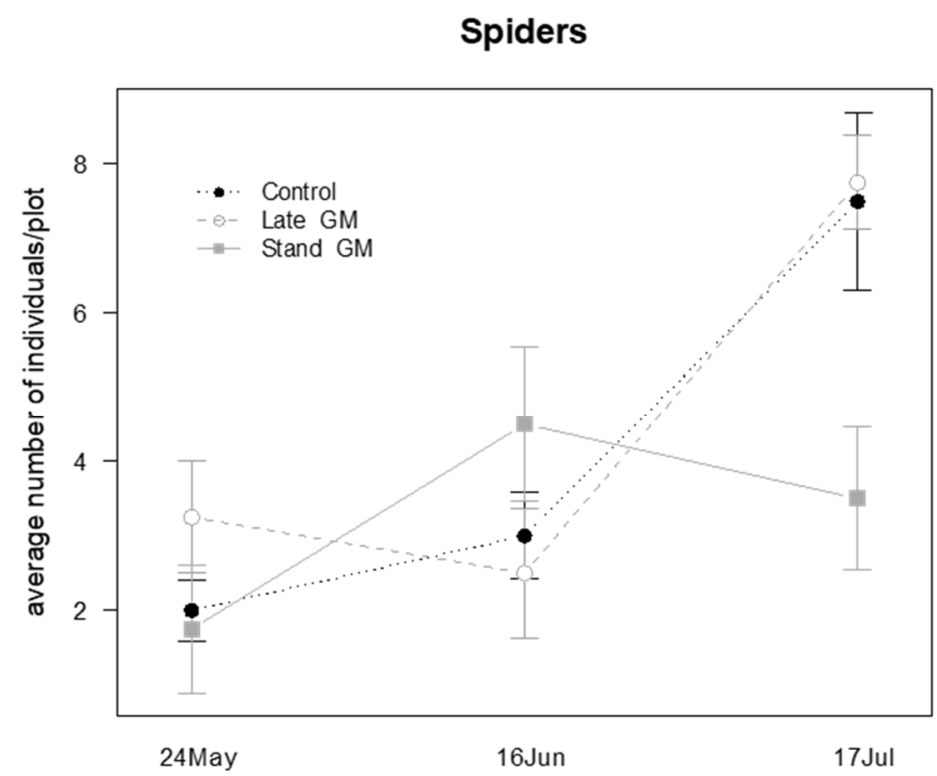

Figure 18. Abundance (mean \pm std. err.) of spiders (Araneae) observed on beating net samples during the second experiment in 2017.

\subsubsection{Sweep Net Sampling}

The use of the sweep net made it possible to collect several arthropods occurring on vineyard inter-row groundcover that were considered in the statistical analysis. During the investigation, the presence of leafhoppers, parasitic wasps, nabids, and spiders was recorded.

The abundance of leafhoppers not associated with grapevine on inter-row vegetation was not affected by the different strategies of groundcover management, but only by the sampling time (Table 10; Figure 19).

Table 10. Results of the mixed-effect model testing the effect of treatment, vineyard management practices, and time of sampling on arthropods collected in sweep net sampling performed in the experiment on the influence of different timing of a green manure mowing. One asterisk $\left(^{*}\right)$ indicates significant effects at $\alpha=0.05$, two asterisks $\left.{ }^{(*}\right)$ indicate significant effects at $\alpha=0.01$, three asterisks $\left.{ }^{* * *}\right)$ indicate significant effects at $\alpha=0.001$.

\begin{tabular}{|c|c|c|c|c|c|}
\hline & Factor or Interaction & d.f. & $F$ & $P$ & \\
\hline \multirow{3}{*}{$\begin{array}{l}\text { Leafhoppers not associated with grapevines } \\
\text { (Hemiptera: Cicadellidae) }\end{array}$} & treatment & $2 ; 9$ & 3.839 & 0.062 & \multirow{3}{*}{$* * *$} \\
\hline & time & $2 ; 17$ & 32.199 & $<0.0001$ & \\
\hline & treatment:time & $4 ; 17$ & 1.126 & 0.377 & \\
\hline \multirow{3}{*}{$\begin{array}{c}\text { Parasitic wasps } \\
\text { (Hymenoptera Apocrita Terebrantia) }\end{array}$} & treatment & $2 ; 9$ & 14.011 & 0.002 & \multirow{3}{*}{$* *$} \\
\hline & time & $2 ; 17$ & 12.532 & 0.001 & \\
\hline & treatment:time & $4 ; 17$ & 2.626 & 0.071 & \\
\hline \multirow{3}{*}{$\begin{array}{c}\text { Ladybirds } \\
\text { (Coleoptera: Coccinellidae) }\end{array}$} & treatment & $2 ; 9$ & 2.583 & 0.130 & \\
\hline & time & $2 ; 17$ & 2.663 & 0.099 & \\
\hline & treatment:time & $4 ; 17$ & 2.599 & 0.073 & \\
\hline \multirow{3}{*}{$\begin{array}{c}\text { Nabids } \\
\text { (Hemiptera: Nabidae) }\end{array}$} & treatment & $2 ; 9$ & 0.424 & 0.667 & \\
\hline & time & $2 ; 17$ & 1.537 & 0.243 & \\
\hline & treatment:time & $4 ; 17$ & 1.878 & 0.161 & \\
\hline \multirow{3}{*}{$\begin{array}{l}\text { Spiders } \\
\text { (Araneae) }\end{array}$} & treatment & $2 ; 9$ & 12.828 & 0.002 & $* *$ \\
\hline & time & $2 ; 17$ & 1.697 & 0.213 & \\
\hline & treatment:time & $4 ; 17$ & 4.139 & 0.016 & * \\
\hline
\end{tabular}

Prior to the analysis average number of individuals was $\log (n+1)$ transformed. 
Leafhoppers not associated with grapevines

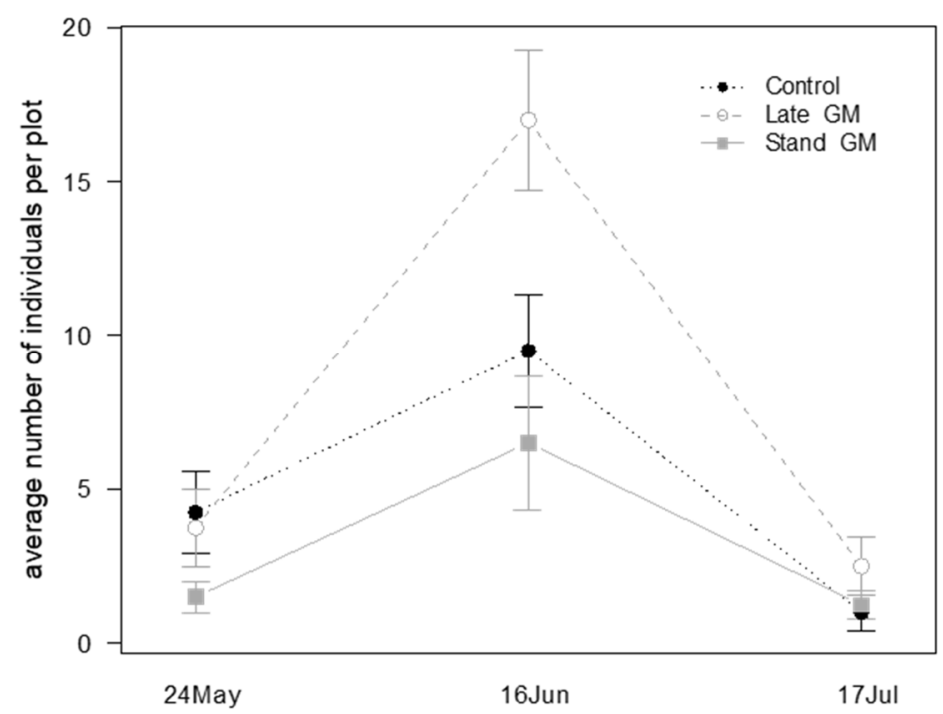

Figure 19. Abundance (mean \pm std. err.) of leafhoppers (Hemiptera: Cicadellidae) observed on sweep net samples during the second experiment in 2017.

The density of parasitic wasps was significantly affected by groundcover management and sampling time, showing a decrease after the withering of the vegetation in the Late-GM plots (Table 10; Figure 20). A higher number of parasitic wasps was observed in Late-GM plots than in Stand-GM plots $(P=0.013)$ and in control plots $(P=0.002)$. The highest difference was observed at the beginning of the observations when the two green manure treatments (Late-GM, Stand-GM) were not differentiated (Figure 20).

\section{Parasitic wasps}

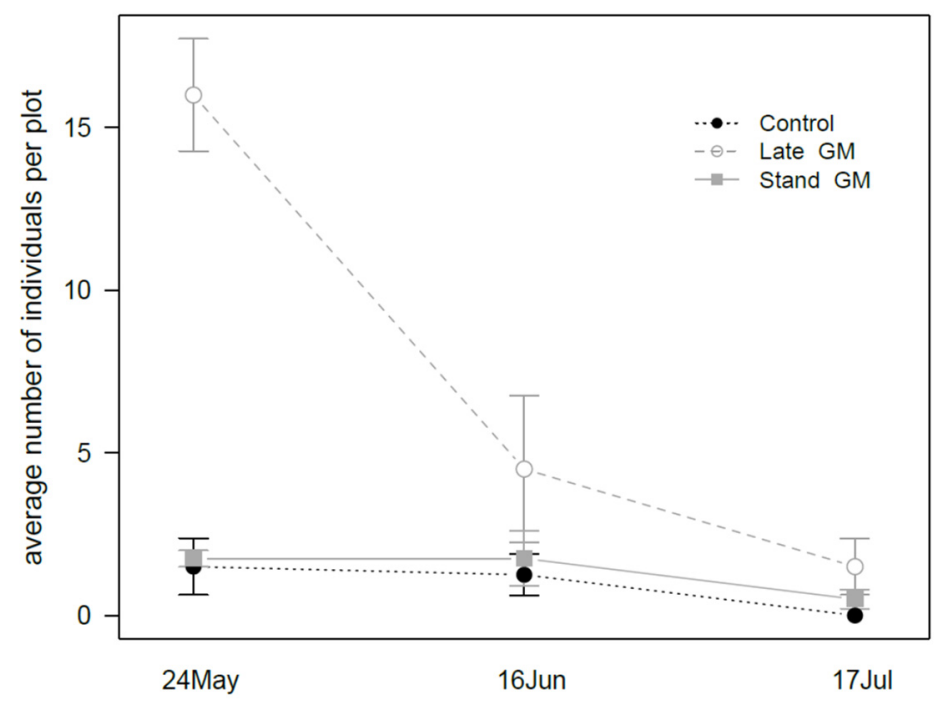

Figure 20. Abundance (mean \pm std. err.) of parasitic wasps (Hymenoptera Apocrita Terebrantia) observed on sweep net samples during the second experiment in 2017.

Spiders were affected by the treatment during the sampling period (Table 10). They were more abundant in Late-GM plots than in Stand-GM $(P<0.001)$ and Control plots $(P<0.001)$, showing a decrease after the withering of the standing vegetation in the LateGM plots (Figure 21). Additionally, in this case, the highest difference was observed at the beginning of the observations when the two green manure treatments (Late-GM, Stand-GM) were not differentiated (Figure 21). 


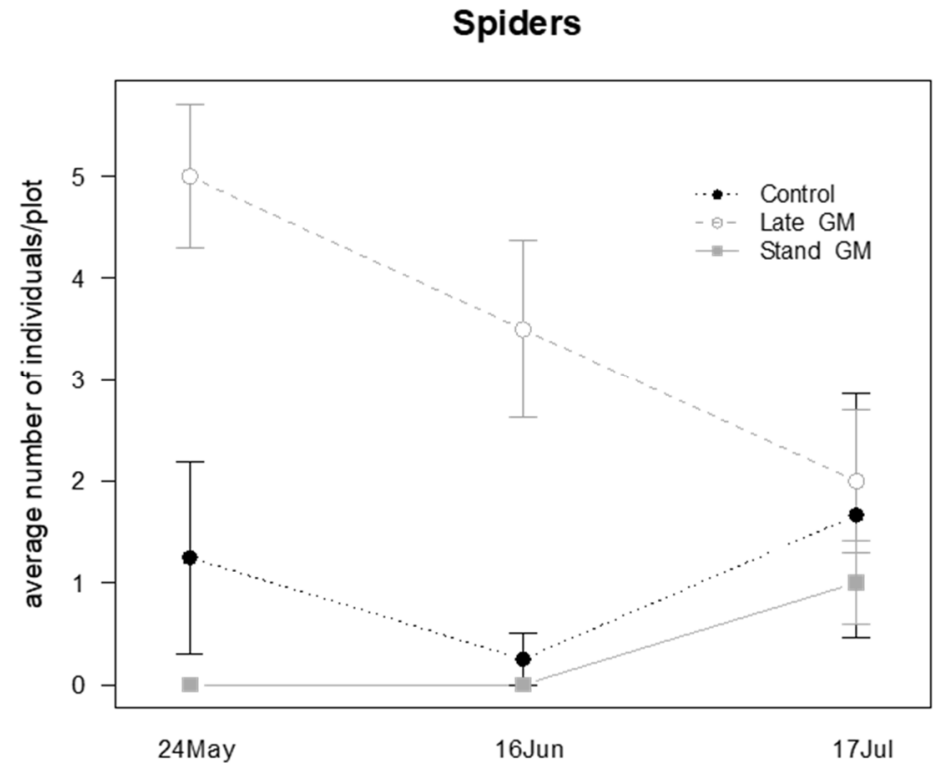

Figure 21. Abundance (mean \pm std. err.) of spiders (Araneae) observed on sweep net samples during the second experiment in 2017.

\subsection{Influence of Different Green Manure Mixtures}

The presence of P. ulmi and of P. finitimus was recorded on leaf samples, but their abundance was not significantly affected by the presence of green manure (Table 11).

Table 11. Results of the mixed-effect model testing the effect of treatment and time of sampling on arthropods on leaves samples collected during the experiment on the influence of different green manure mixtures. One asterisk $\left(^{*}\right)$ indicates significant effects at $\alpha=0.05$, two asterisks ${ }^{* *}$ ) indicate significant effects at $\alpha=0.01$, three asterisks ${ }^{* * *}$ ) indicate significant effects at $\alpha=0.001$.

\begin{tabular}{ccccc}
\hline & Factor or Interaction & d.f. & $\boldsymbol{F}$ & $\boldsymbol{P}$ \\
\hline Panonychus ulmi & treatment & $3 ; 11$ & 0.809 & 0.515 \\
(Acari: Tetranychidae) & time & $2 ; 21$ & 0.126 & 0.883 \\
& treatment:time & $6 ; 21$ & 0.414 & 0.861 \\
\hline Phytoseius finitimus & treatment & $3 ; 11$ & 0.536 & 0.667 \\
(Acari: Phytoseiidae) & time & $2 ; 21$ & 6.232 & 0.008 \\
& treatment:time & $6 ; 21$ & 1.494 & 0.228 \\
\hline Empoasca vitis & treatment & $3 ; 11$ & 0.413 & 0.747 \\
(Hemiptera: Cicadellidae) & time & $2 ; 21$ & 11.697 & 0.001 \\
Zygina rhamni & treatment:time & $6 ; 21$ & 1.015 & 0.442 \\
(Hemiptera: Cicadellidae) & treatment & $3 ; 12$ & 0.497 & 0.691 \\
$* * *$ \\
Erasmoneura vulnerata & time & $2 ; 23$ & 9.558 & 0.001 \\
(Hemiptera: Cicadellidae) & treatment:time & $6 ; 23$ & 0.930 & 0.492 \\
\hline
\end{tabular}

Prior to the analysis average number of individuals was $\log (n+1)$ transformed.

The presence of E. vitis, Z. rhamni and E. vulnerata was observed in leaf samples, but their abundance did not differ among treatments, while the effect of sampling time emerged in the analysis (Table 11).

During the observation of leaf samples, predatory thrips, eggs of lacewings, and larvae of ladybirds were observed but they were not considered in the analysis due to their low abundance. 


\section{Discussion}

In the first trial, the presence of non-mowed vegetation in the vineyard inter-rows influenced the abundance of arthropods on grapevine canopy and/or inside the vineyard agro-ecosystem. On grapevine leaves, the higher number of predatory mites observed in plots with non-mowed vegetation is likely related to the higher amount of pollen provided by flowering plants. Pollen has been shown to serve as alternative food for phytoseiid mites [24]. Moreover, in the first experiment the higher presence of natural enemies, such as parasitic wasps and assassin bugs, on non-mowed inter-row vegetation was related to the presence of standing vegetation, which provides food sources (such as pollen and nectar), refuge zone and alternative prey (e.g., aphids, data not shown) $[2,16,25]$. A higher presence of spiders was also recorded on vine canopy close to non-mowed inter-rows; standing vegetation also favored the presence of spiders by providing habitat and food sources (insects and mites on the vegetation are potential prey), as observed in Californian vineyards [26,27]. In fact, weeds are important components of the vineyard agro-ecosystems, since they support alternative prey/hosts, pollen or nectar as well as microhabitats that are unavailable in weeded monocultures [2,25]. The higher plant biodiversity, which provides several resources for beneficial arthropods, can contribute to create an appropriate ecological infrastructure within the vineyards resulting in a more pest-stable agro-ecosystems [11-14]. Nevertheless, the presence of non-mowed vegetation inside the vineyard can also favor the occurrence of some pests, as reported for S. titanus by Trivellone et al. [28]. In the present study, higher densities of Z. rhamni and S. titanus were observed in organic vineyards, in particular in plots with standing vegetation. Regarding Z. rhamni, recorded on grapevine leaves, this result is likely influenced by the use of botanical insecticides (e.g., pyrethrins), which are less effective in controlling leafhoppers populations compared to conventional insecticides $[29,30]$. Scaphoideus titanus was recorded only on the NM inter-row vegetation, which may offer better micro-climatic conditions, food and refuges. In particular, the presence of standing vegetation could make the control of $S$. titanus populations harder in organic vineyards, considering its important role in the spread of the Flavescence dorée.

Regarding the parasitism rate of leafhoppers eggs, no differences were recorded confirming trends observed by Nicholls et al. [26] in their studies on cover crops. They argued that mowing of cover crops forced egg parasitoids to move to adjacent plots, so no differences were observed between treatments.

The number of organic vineyards is increasing in Europe, and this tendency is expected to increase following the implementation of the Farm to Fork strategy by the European Union, which is explicitly aimed at increasing the agricultural land under organic farming [31,32]. In the present study, we observed a significant effect of vineyard management practices on the abundance of some arthropods (e.g., earwigs and spiders). Their presence was more abundant in organic than in conventional vineyards or was detected only in the first ones. These results partially agree with those obtained by Caprio et al. [33] where organic crop systems sustained a higher diversity of carabids and spiders. The meta-analysis conducted by Bengtsson et al. [34] showed that organic farming often has positive effects on species richness and abundance, and they found that the effects differed between arthropod groups and landscapes.

The results of the second experiment showed that different timing of mowing of the green manure sown in the vineyard inter-rows can influence the arthropod patterns on grapevine canopy and/or inside the vineyard agro-ecosystem. The abundance of predatory mites on leaves was not significantly affected by green manure, while spider mite populations were more abundant in the control plots. Similar results were obtained by Flaherty [15], who observed relatively lower population density of the phytophagous Pacific mite, Eotetranychus willamettei Ewing (Acari: Tetranychidae), on vines in plots where weeds were allowed to grow. In fact, in plots with spontaneous vegetation, the presence of a managed groundcover of Sorghum halepense (Poaceae) supported populations of the predatory mite Metaseiulus occidentalis (Nesbitt) (Acari: Phytoseiidae), maintaining the Pacific mite below the economically damaging threshold. The grass supported an 
alternative host for the predatory mite, who colonized adjacent vines sufficiently early to suppress the pest-mite populations.

In this experiment, the presence of green manure also favored the abundance of some beneficial arthropods, such as spiders and parasitic wasps. They were more abundant on both late and standard mowed green manure strips as compared to the control plots and, for spiders, also on vine canopy adjacent to plots where green manure was mowed later. The presence of the standing vegetation provides habitat and food sources for natural enemies, as observed in the previous trial on the groundcover management and in other studies [26,27]. Cover plants like alyssum, buckwheat and "vetch-oat" showed attractiveness to some Hymenopteran parasitoid taxa in vineyards [35], but the response of a particular family depended on the plant species. Surface mulches increased soil invertebrate abundance, including spiders in Australian vineyards [36]. In other experiments in Northern Italy, some ground covers like Faba bean and "vetch-oats" caused an increase of spiders attending the flowering plant canopy [35].

Regarding phytophagous insects, the leafhoppers and stink bugs were not significantly affected by the different timing of green manure mowing. Therefore, our data suggest that green manure strips do not promote an increase in pest abundance. The same result was obtained in other studies in Northern Italy, where different cover grounds did not increase Homoptera populations in comparison with conventional soil management [35]; the only exception was Alyssum, which revealed some attraction toward this taxon, though results were affected by sampling techniques. Another study suggests that cover crops may promote the development of vine mealybug populations compared to conventional soil management [37].

The non-significant results obtained in the third experiment, on the effects of different green manure mixtures on arthropods abundance on leaves, could be probably related to the low distance between sampling plots (only $3 \mathrm{~m}$ ), which cannot impede the aerial dispersal of both pollen of flowering plants [38] and of predatory mites [39]. Moreover, grapevine leafhoppers can also actively move among the vines [40]. In other studies, in Northern Italy, phytoseiid eggs and mobile stages showed a significant increase on leaves of vines in large plots managed with different ground covers in comparison with conventional management of natural vegetation [35]. The use of small experimental or not isolated plots could represent a limitation for this type of study because of potential interference between contiguous plots. This aspect probably affected the results obtained in the third experiment, while the two other experiments were performed in larger and more isolated plots.

In conclusion, the increase of unmowed vegetation in vineyard inter-rows can be achieved by alternating mowing that could be a useful practice to increase natural enemies [11,12]. This practice is increasingly adopted by the growers with the aim of enhancing biodiversity at vineyard level [41]. However, the result obtained here highlight that its adoption should be carefully considered in organic vineyards where $S$. titanus occurs. Further studies should investigate if the timing of mowing can favor the dispersal of beneficial arthropods from the inter-row vegetation to the grapevine canopy. It has been shown that the mowing of the herbaceous vegetation can force the migration of parasitoids and predators from margins inside the cultivated fields [42] or from cover crops to vine canopy [26]. The timing of mowing must be accurately planned according to the life cycle of natural enemies in order to optimize this practice [43]. It should be mentioned that the frequent grass mowing can promote the dispersal of Hyalesthes obsoletus Signoret (Hemiptera: Cixiidae), a vector of phytoplasma associated with Bois noir disease on the grapevine [44].

Allowing the green manure to flower for a prolonged period instead of the traditional practice of early mowing may favor a higher presence and abundance of beneficial arthropods. This field experiment was carried out in a very simplified context, where the presence of semi-natural habitats in the surrounding area was very low (less than $4 \%$ in a radius of $500 \mathrm{~m}$ ); this could have determined a low availability of natural enemies inside the vineyard agro-ecosystem during the experiment. Green manure is a practice that is 
increasingly being adopted in vineyards for its beneficial effects on soil quality [45]. The presence of green manure can support an increase of plant biodiversity inside the vineyard, contributing to the provision of fundamental resources for beneficial arthropods [46]. However, the presence of temporary vegetation appears to be insufficient on its own to create a more pest-stable agro-ecosystem; it should be integrated with an appropriated ecological infrastructure surrounding the vineyards [11-14]. Further studies should clarify whether the positive effect on natural enemies found here have implications on the control of grapevine pests.

Author Contributions: Conceptualization, G.Z., A.P. and C.D.; methodology, G.Z., A.P. and C.D.; validation, A.P. and C.D.; formal analysis, G.Z.; investigation, G.Z. and A.B.; data curation, G.Z. and A.B.; writing—original draft preparation, G.Z. and C.D.; writing—review and editing, G.Z., G.B. and C.D.; visualization, G.Z.; All authors have read and agreed to the published version of the manuscript.

Funding: This work was partially supported by the projects BIRD167802/16 to A.P. and DOR (University of Padova) to C.D. and A.P.

Institutional Review Board Statement: Not applicable.

Informed Consent Statement: Not applicable.

Data Availability Statement: The data presented in this study are available from the corresponding author, upon reasonable request.

Acknowledgments: We thank F. Pavan (University of Udine) for comments to the manuscript, F. Scortegagna, F. Taglietti and A. Battistella for the selection of farms, as well as farmers hosting experiments (in particular Corvezzo Winery). We thank the Academic Editor and two reviewers for their constructive comments, which helped us to improve the manuscript.

Conflicts of Interest: The authors declare no conflict of interest.

\section{References}

1. Corbett, A.; Rosenheim, J.A. Impact of a natural enemy overwintering refuge and its interaction with the surrounding landscape. Ecol. Entomol. 1996, 21, 155-164. [CrossRef]

2. Landis, D.A.; Wratten, S.D.; Gurr, G.M. Habitat management to conserve natural enemies of arthropod pests in agriculture. Annu. Rev. Entomol. 2000, 45, 175-201. [CrossRef]

3. Van Emden, H.F. Conservation biological control: From theory to practice. In Proceedings of the 1st International Symposium on Biological Control of Arthropods, Honolulu, HI, USA, 14-18 January 2002; Van Driesche, R.G., Ed.; USDA Forest Service, Forest Health Technology Enterprise Team: Morgantown, WV, USA, 2003; pp. 14-18.

4. Hardin, M.R.; Benrey, B.; Coll, M.; Lamp, W.O.; Roderick, G.K.; Barbosa, P. Arthropod pest resurgence: An overview of potential mechanisms. Crop Prot. 1995, 14, 3-18. [CrossRef]

5. Johnson, M.W.; Tabashnik, B.E. Enhanced biological control through pesticide selectivity. In Handbook of Biological Control, 1st ed.; Fisher, T.W., Bellows, T.S., Caltagirone, L.E., Dahlsten, D.L., Huffaker, C.B., Gordh, G., Eds.; Academic Press: San Diego, CA, USA, 1999; pp. 297-317.

6. Symondson, W.O.C.; Sunderland, K.D.; Greenstone, M.H. Can generalist predators be effective biocontrol agents? Annu. Rev. Entomol. 2002, 47, 561-594. [CrossRef]

7. Schmidt, M.H.; Thies, C.; Tscharntke, T. Landscape context of arthropod biological control. In Ecological Engineering for Pest Management: Advances in Habitat Manipulation for Arthropods; Gurr, G.M., Wratten, S.D., Altieri, M.A., Eds.; CSIRO Publishing: Collingwood, Australia, 2004; pp. 55-63.

8. Thorbek, P.; Bilde, T. Reduced numbers of generalist arthropod predators after crop management. J. Appl. Ecol. 2004, 41, 526-538. [CrossRef]

9. Bianchi, F.J.; Booij, C.J.H.; Tscharntke, T. Sustainable pest regulation in agricultural landscapes: A review on landscape composition, biodiversity and natural pest control. Proc. R. Soc. Lond. B Biol. Sci. 2006, 273, 1715-1727. [CrossRef]

10. Tsitsilas, A.; Stuckey, S.; Hoffmann, A.A.; Weeks, A.R.; Thomson, L.J. Shelterbelts in agricultural landscapes suppress invertebrate pests. Aust. J. Exp. Agric. 2006, 46, 1379-1388. [CrossRef]

11. Altieri, M.A.; Nicholls, C.I. Biodiversity and Pest Management in Agroecosystems, 2nd ed.; CRC Press: Boca Raton, FL, USA, 2004; pp. 1-252.

12. Gurr, G.M.; Scarratt, S.L.; Wratten, S.D.; Berndt, L.; Irvin, N. Ecological engineering, habitat manipulation and pest management. In Ecological Engineering for Pest Management: Advances in Habitat Manipulation for Arthropods; Gurr, G.M., Wratten, S.D., Altieri, M.A., Eds.; CSIRO Publishing: Collingwood, Australia, 2004; pp. 1-12. 
13. Begum, M.; Gurr, G.M.; Wratten, S.D.; Nicol, H.I. Flower color affects tri-trophic-level biocontrol interactions. Biol. Control 2004, 30, 584-590. [CrossRef]

14. Altieri, M.A.; Ponti, L.; Nicholls, C.I. Manipulating vineyard biodiversity for improved insect pest management: Case studies from northern California. Int. J. Biodiv. Sci. Manag. 2005, 1, 191-203. [CrossRef]

15. Flaherty, D.L. Ecosystem trophic complexity and densities of the Willamette mite, Eotetranychus willamettei Ewing (Acarina: Tetranychidae). Ecology 1969, 50, 911-916. [CrossRef]

16. Irvin, N.A.; Hoddle, M.S. The effect of buckwheat flowers and cahaba vetch on fitness of the vine mealybug parasitoid Anagyrus pseudococci (Hymenoptera: Encyrtidae). Fla. Entomol. 2015, 237-242. [CrossRef]

17. Duso, C.; Malagnini, V.; Paganelli, A.; Aldegheri, L.; Bottini, M. Pollen availability and phytoseiid abundance (Acari: Phytoseiidae) on natural and secondary hedgerows. BioControl 2004, 49, 397-415. [CrossRef]

18. Duso, C.; Pozzebon, A.; Kreiter, S.; Tixier, M.S.; Candolfi, M.P. Management of phytophagous mites in European vineyards. In Arthropod Management in Vineyards: Pests, Approaches, and Future Directions; Bostanian, N.J., Vincent, C., Isaacs, R., Eds.; Springer: Dordrecht, The Netherlands, 2012; pp. 191-217.

19. Altieri, M.A.; Nicholls, C.I.; Wilson, H.; Miles, A. Habitat Management in Vineyards. A Growers Manual for Enhancing Natural Enemies; College of Natural Resources, Laboratory of Agroecology, University of California: Berkeley, CA, USA, 2010 ; pp. 1-21.

20. Wäckers, F.L. Assessing the suitability of flowering herbs as parasitoid food sources: Flower attractiveness and nectar accessibility. Biol. Control 2004, 29, 307-314. [CrossRef]

21. Schvester, D.; Carle, P.; Moutous, G. Transmission de la flavescence dorée de la vigne par Scaphoideus littoralis Ball. Ann. Epiphyt. 1963, 14, 175-198.

22. R Core Team. R: A Language and Environment for Statistical Computing; R Foundation for Statistical Computing: Vienna, Austria, 2013; Available online: http:/ / www.R-project.org/ (accessed on 1 January 2013).

23. Pinheiro, J.; Bates, D.; DebRoy, S.; Sarkar, D.; R Core Team. nlme: Linear and Nonlinear Mixed Effects Models; R Package Version 3.1-120; 2015 Available online: https:/ / cran.r-project.org/web/packages/nlme/citation.html (accessed on 5 February 2020).

24. McMurtry, J.A.; Croft, B.A. Life-styles of phytoseiid mites and their roles in biological control. Annu. Rev. Entomol. 1997, 42, 291-321. [CrossRef]

25. Altieri, M.A.; Whitcomb, W.H. Weed manipulation for insect pest management in corn. Environ. Manag. 1980, 4, 483-489. [CrossRef]

26. Nicholls, C.I.; Parrella, M.P.; Altieri, M.A. Reducing the abundance of leafhoppers and thrips in a northern California organic vineyard through maintenance of full season floral diversity with summer cover crops. Agric. For. Entomol. 2000, 2, 107-113. [CrossRef]

27. Daane, K.M.; Hogg, B.N.; Wilson, H.; Yokota, G.Y. Native grass ground covers provide multiple ecosystem services in Californian vineyards. J. Appl. Ecol. 2018, 55, 2473-2483. [CrossRef]

28. Trivellone, V.; Jermini, M.; Linder, C.; Cara, C.; Delabays, N.; Baumgartner, J. Rôle de la flore du vignoble sur la distribution de Scaphoideus titanus. Rev. Suisse Vitic. Arboric. Hortic. 2013, 45, 222-228.

29. Mori, N.; Tonello, D.; Posenato, G.; Pozzebon, A.; Duso, C. Efficacy of biopesticides against Scaphoides titanus Ball in different experimental conditions. IOBC/WPRS Bull. 2014, 105, 45-48.

30. Tacoli, F.; Mori, N.; Pozzebon, A.; Cargnus, E.; Da Vià, S.; Zandigiacomo, P.; Duso, C.; Pavan, F. Control of Scaphoideus titanus with natural products in organic vineyards. Insects 2017, 8, 129. [CrossRef] [PubMed]

31. Merot, A.; Ugaglia, A.A.; Barbier, J.M.; Del'homme, B. Diversity of conversion strategies for organic vineyards. Agron. Sustain. Dev. 2019, 39, 1-11. [CrossRef]

32. Farm to Fork Strategy. A Farm to Fork Strategy for a Fair, Healthy and Environmentally-Friendly Food System. Communication from the Commission to the European Parliament, the Council, the European Economic and Social Committee and the Committee of the Regions; COM/2020/381 Final. Available online: https:/ /ec.europa.eu/food/sites/food/files/safety/docs/f2f_ actionplan_2020_strategy-info_en.pdf (accessed on 20 October 2020).

33. Caprio, E.; Nervo, B.; Isaia, M.; Allegro, G.; Rolando, A. Organic versus conventional systems in viticulture: Comparative effects on spiders and carabids in vineyards and adjacent forests. Agric. Syst. 2015, 136, 61-69. [CrossRef]

34. Bengtsson, J.; Ahnström, J.; Weibull, A.C. The effects of organic agriculture on biodiversity and abundance: A meta-analysis. J. Appl. Ecol. 2005, 42, 261-269. [CrossRef]

35. Burgio, G.; Marchesini, E.; Reggiani, N.; Montepaone, G.; Schiatti, P.; Sommaggio, D. Habitat management of organic vineyard in Northern Italy: The role of cover plants management on arthropod functional biodiversity. Bull. Entomol. Res. 2016, 106, 759-768. [CrossRef] [PubMed]

36. Thomson, L.J.; Hoffmann, A.A. Effects of ground cover (straw and compost) on the abundance of natural enemies and soil macro invertebrates in vineyards. Agric. For. Entomol. 2007, 9, 173-179. [CrossRef]

37. Muscas, E.; Cocco, A.; Mercenaro, L.; Cabras, M.; Lentini, A.; Porqueddu, C.; Nieddu, G. Effects of vineyard floor cover crops on grapevine vigor, yield, and fruit quality, and the development of the vine mealybug under a Mediterranean climate. Agric. Ecosyst. Environ. 2017, 237, 203-212. [CrossRef]

38. Raynor, G.S.; Hayes, J.V.; Ogden, E.C. Mesoscale transport and dispersion of airborne pollens. J. Appl. Meteorol. 1974, 13, 87-95. [CrossRef] 
39. Tixier, M.S.; Kreiter, S.; Auger, P.; Weber, M. Colonization of Languedoc vineyards by phytoseiid mites (Acari: Phytoseiidae): Influence of wind and crop environment. Exp. Appl. Acarol. 1998, 22, 523-542. [CrossRef]

40. Decante, D.; Van Helden, M. Spatial and temporal distribution of Empoasca vitis within a vineyard. Agric. For. Entomol. 2008, 10, 111-118. [CrossRef]

41. Malavolta, C.; Duso, C. IOBC/WPRS Crop Specific Technical Guidelines for Integrated Production of Grapes, 5th ed.; International Organisation for Biological and Integrated Control (IOBC)/West Palearctic Regional Section (WPRS): Zürich, Switzerland, 2020.

42. Perrin, R.M. The role of the perennial stinging nettle, Urtica dioica, as a reservoir of beneficial natural enemies. Ann. Appl. Biol. 1975, 81, 289-297. [CrossRef]

43. Van den Bosch, R.; Telford, A.D. Environmental modification and biological control. In Biological Control of Insect Pests and Weeds; DeBach, P., Ed.; Reinhold Publ. Co.: New York, NY, USA, 1964; pp. 459-488.

44. Mori, N.; Pozzebon, A.; Duso, C.; Reggiani, N.; Pavan, F. Vineyard colonization by Hyalesthes obsoletus (Hemiptera: Cixiidae) induced by stinging nettle cut along surrounding ditches. J. Econ. Entomol. 2015, 109, 49-56. [CrossRef] [PubMed]

45. Longa, C.M.; Nicola, L.; Antonielli, L.; Mescalchin, E.; Zanzotti, R.; Turco, E.; Pertot, I. Soil microbiota respond to green manure in organic vineyards. J. Appl. Microbiol. 2017, 123, 1547-1560. [CrossRef] [PubMed]

46. Wilson, H.; Daane, K.M. Review of ecologically-based pest management in California vineyards. Insects 2017, 8, 108. [CrossRef] [PubMed] 